
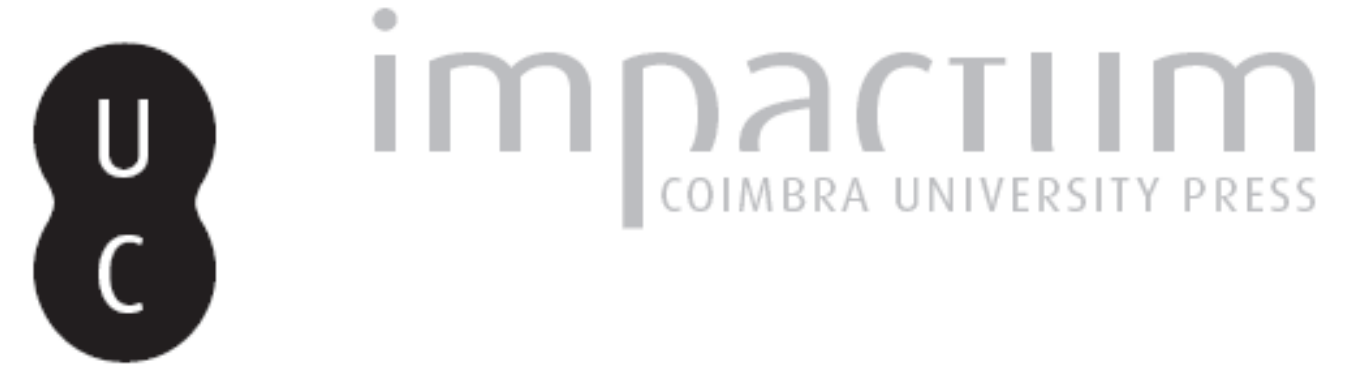

\title{
Arqueologia e ideologia: o caso germânico
}

Autor(es): $\quad$ Mantas, Vasco Gil

Publicado por: Imprensa da Universidade de Coimbra

URL persistente:

URI:http://hdl.handle.net/10316.2/45003

DOI:

DOI:https://doi.org/10.14195/0870-4147_38_8

Accessed : $\quad$ 26-Apr-2023 09:57:15

A navegação consulta e descarregamento dos títulos inseridos nas Bibliotecas Digitais UC Digitalis, UC Pombalina e UC Impactum, pressupõem a aceitação plena e sem reservas dos Termos e Condições de Uso destas Bibliotecas Digitais, disponíveis em https://digitalis.uc.pt/pt-pt/termos.

Conforme exposto nos referidos Termos e Condições de Uso, o descarregamento de títulos de acesso restrito requer uma licença válida de autorização devendo o utilizador aceder ao(s) documento(s) a partir de um endereço de IP da instituição detentora da supramencionada licença.

Ao utilizador é apenas permitido o descarregamento para uso pessoal, pelo que o emprego do(s) título(s) descarregado(s) para outro fim, designadamente comercial, carece de autorização do respetivo autor ou editor da obra.

Na medida em que todas as obras da UC Digitalis se encontram protegidas pelo Código do Direito de Autor e Direitos Conexos e demais legislação aplicável, toda a cópia, parcial ou total, deste documento, nos casos em que é legalmente admitida, deverá conter ou fazer-se acompanhar por este aviso.

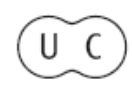



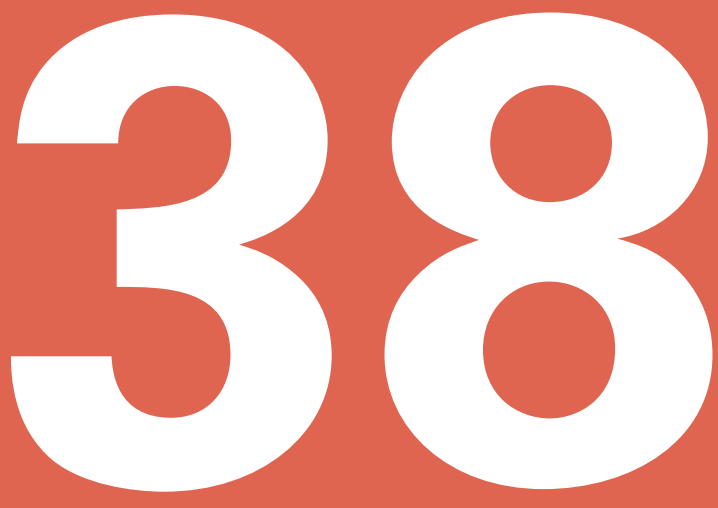

\section{Revista Portuguesa de História}

Faculdade de Letras da Universidade de Coimbra Instituto de História Económica e Social

Coimbra 08 
Revista Portuguesa de História

t. XXXVIII (2006)

pp. 181-217

\section{Arqueologia e Ideologia. O Caso Germânico}

VAsco Gil Mantas

Universidade de Coimbra

Os condicionalismos a que a investigação tem sido sujeita no campo das ciências históricas e arqueológicas ${ }^{1}$, desde que estas ganharam estatuto de verdadeiras actividades científicas, têm constituído tema para nutridos artigos, menos numerosos do que seria de esperar perante a constante intromissão de factores de ordem ideológica na elaboração da História que se publica. São muitas as razões que o determinam e não apenas políticas, no sentido restrito do termo, pois emanam de circunstâncias tão diversas como as que se relacionam com a religião, a economia, os interesses de grupo e, não esqueçamos, as modas culturais. Tivemos já oportunidade de aludir a esta questão fundamental da investigação histórica e arqueológico ${ }^{2}$, pois se trata da expressão pública dos resultados obtidos por ramos privilegiados das ciências humanas, naturalmente das mais vulneráveis, directa ou indirectamente, ao ambiente social da época e do

1 P. Stone / R. Mackenzie (Ed.), The Excluded Past: Archaeology in Education, Londres, 1989; S. Jones, The Archaeology of Ethnicity. Constructing Identities in the Past and Present, Londres, 1997, p. 1-14; G. Thuillier / J. Tulard, Le marché de l'histoire, Paris, 1994, p. 6-9, 31-32. Agradecemos cordialmente ao Dr. Luís Madeira o tratamento das imagens deste artigo.

2 V. Mantas, Arqueologia e História Antiga: dos monumentos aos homens de ontem e de hoje, “As Oficinas da História”, Coimbra, 2002, p. 103-129. 
lugar onde se desenvolvem, ciências quase sempre comprometidas com os Idealtypen de uma determinada sociedade, seja pela afirmativa concordante ou pela negativa contestatária.

Não nos iludamos, como tantas vezes sucede, com a ideia simplista de que a influência ideológica se exerce sobre a investigação apenas em países onde vigoram ou vigoraram regimes que classificaremos, para simplificar, como totalitários, à imagem do que Huxley e Orwell escreveram sobre o controlo da Cultura e da História com fins políticos, limitando-se, afinal, a evocar realidades do mundo contemporâneo ${ }^{3}$. Embora mais subtis, ou sem programa definido, não é difícil encontrar situações semelhantes em sociedades que se consideram livres, obrigando a uma análise pontual no sentido de lhes determinar a origem e o objectivo. Seja como for, é evidente que estamos ainda longe de conhecer uma investigação histórica e arqueológica imparcial, não comprometida e isenta de condicionalismos, situação que perdurará no futuro com maior ou menor pertinência consoante o enquadramento social e político que conhecer.

O panorama da Europa contemporânea é particularmente favorável ao fantasma dos mitos identitários que têm assombrado o trabalho de tantos investigadores notáveis, como sucedeu amiúde no século XX. A necessidade de integração num grupo, com características e códigos próprios, faz parte da natureza humana, que exige, da mesma forma, um passado comum, uma memória, que o distinga dos restantes. O recurso aos dados arqueológicos, inevitável e essencial para a história mais recuada de vastas regiões europeias, ocorre como a solução mais prática para justificações unitárias, através de interpretações generalizadoras dificilmente aceitáveis do ponto de vista científico, repetindo, afinal, uma linguagem já tantas vezes utilizada. Compreensível, no contexto político actual, em regiões que procuram afirmar ou reafirmar a sua identidade no interior de estados sem unidade cultural ou étnica, encontramo-la também quando se pretende transmitir uma imagem de passado comum para o espaço crescente da União Europeia, apoiando-se na Idade do Bronze, numa visão eclética do Celtismo ou, com maior dificuldade por razões de evidente desajustamento, mas com muita frequência, na imagem teórica do Império Romano ${ }^{4}$.

3 A. Huxley, Admirável Mundo Novo, Lisboa, 1976, p. 42-43, 56; G. Orwell, 1984, Lisboa, s/d, p. 41-53. Estas duas formidáveis anti-utopias permanecem completamente actuais, para além de todas as transformações políticas que marcaram o fim do século XX, ou talvez por isso mesmo.

4 S. Jones / P. Graves-Brown, Introduction: archaeology and cultural identity in Europe, "Cultural Identity and Archaeology. The Construction of European Communities", Londres, 1996, p. 1-24; C. Shore, Imagining the new Europe: identity and heritage in European Community 
Este processo de configuração artificial de um passado aceitável por todos os membros de uma comunidade cada vez mais difícil de definir em termos geográficos e culturais, a qual parece derivar para uma entidade meramente política e económica, assenta largamente na manipulação de dados arqueológicos, sobretudo a nível da divulgação, circunstância que tem provocado reacções de tonalidade diversa entre os arqueólogos mais preocupados com o fenómeno ${ }^{5}$. Ao mesmo tempo que se esboçam estes cenários, como reflexos de uma unidade perdida e a recuperar, emergem ou ganham nova força, imaginários regionalistas, cuja principal diferença em relação aos nacionalismos é de ordem quantitativa, imaginários pouco contrariados pela filosofia subjacente à Europa das Regiões, o que constitui uma contradição apenas na aparência. Na realidade, a História mostra dramaticamente que o princípio da unidade na diversidade, quando envolvendo grandes espaços, só pode desenvolver-se a partir do exercício de uma hegemonia, como em tempos sucedeu, por exemplo, com o Império Romano ou, mais recentemente, com o Império Austro-Húngaro. A unidade é um luxo a que raros estados podem aspirar, pelo menos quando se trata daqueles elementos em que, tradicionalmente, se baseava a consciência nacional, com particular destaque para a raça e a língua, o que leva, quando necessário e em condições favoráveis, à elaboração de um conjunto de elementos reconhecidos e aceites como comuns, dinamizadores de uma unidade artificial, elementos normalmente projectados num passado muito remoto, particularmente apto à reconstituição arqueológica. Assim aconteceu na Alemanha nacional-socialista com o Germanismo, embora por razões políticas mais complexas, uma vez que a questão da língua e das minorias étnicas se apresentava, no seu território, de forma bastante mitigada.

Admitida a dificuldade, se não a impossibilidade de atingir a verdade histórica que existe algures atrás dos testemunhos arqueológicos, relegando-a a uma situação de ideal a não atingir, compreende-se perfeitamente que a utilização não científica dos dados facultados pela Arqueologia no sentido de provar um qualquer a priori político ou cultural corresponda a uma opção redundante. Neste artigo desenvolvemos uma breve análise em torno da forma como foi gerida a investigação arqueológica como suporte de um Germanismo militante, preocupado em justificar um estatuto de superioridade

discourse, "Cultural Identity and Archaeology. The Construction of European Communities", Londres, 1996, p. 115.

5 G. R. Zapatero, Celts and Iberians. Ideological manipulation in Spanish archaeology, "Cultural Identity and Archaeology. The Construction of European Communities", Londres, 1996, p. 179-195; A. P. Fitzpatrick, "Celtic” Iron Age Europe, "Cultural Identity and Archaeology. The Construction of European Communities", Londres, 1996, p. 238-255. 
racial e cultural, assim como o direito à posse de territórios de alguma forma considerados germânicos num dado momento da História ou da Pré-História. Embora esta política defensora de uma Grande Alemanha tenha conhecido o apogeu, naturalmente, durante os doze anos de duração do chamado III Reich, a verdade é que contou com antecedentes, particularmente no século XIX, quando o Pangermanismo se torna uma ideia dominante, ainda que, por essa altura a língua e não tanto a raça constituisse o elemento essencial. A existência, na Europa, de importantes grupos populacionais de origem ou de língua alemã fora da Alemanha, devido a vicissitudes históricas diversas, estimulou uma política mais ou menos activa, sobretudo naqueles casos de contiguidade territorial, tendente a integrar tais populações. Se o caso alsaciano é o mais conhecido, não podemos esquecer outros, circunstancialmente agravados pelas determinações do Tratado de Versalhes e do Tratado de Saint-Germain-en-Laye, após o final da Primeira Guerra Mundial, assim como o problema das comunidades alemãs isoladas em solo estrangeiro, como as do Volga, na Rússia, ou da Roménia, em especial na região de Timisoara, dramaticamente evocada num famoso romance de Virgil Georghiu'.

Um interessante opúsculo de propaganda, publicado em língua portuguesa no início da II Guerra Mundial, aborda, com a concisão e a segurança próprias deste tipo de literatura, testemunho fundamental da ideologia oficial, num breve sumário da história alemã, a questão da origem e expansão dos Germanos: Os princípios do germanismo encontram-se nas tribus da Idade da Pedra Lascada, que habitaram as costas ocidentais do Mar Báltico, entre o $6^{\circ}$ e o $2^{\circ}$ milénio a.C. e dos quais resultou na Idade do Bronze (cêrca de 2000 a 750 a.C.) a cultura dos antigos camponeses germânicos altamente desenvolvida. Com o alastramento destas colónias sobre o território da Alemanha actual, surgem as tribus da chamada grande época germânica que fundaram por toda a Europa, em campanhas aventurosas, os seus Impérios: os visigodos na Espanha, os ostrogodos na Itália, os vandalos até na África do Norte, os langobardos na Itália do Norte, os francos na região do Reno, e os parentes anglo-saxões na Inglaterra ${ }^{7}$.

Um pouco adiante, o autor do livrinho volta referir o mesmo tema, agora a propósito da origem do povo alemão, escrevendo: Desde a fixação e expansão das principais tribus germânicas no espaço entre o Reno e o Vístula, foram assimilados por este novo campo de forças alemão tanto os elementos marginais

6 R. Wolfram, Die Germanischen Völker, "Die Grosser Völker Kunde”, I, Lípsia, 1939, p. 73-112; V. Georghiu, A Vigésima Quinta Hora, Lisboa, s/d.

7 M. Herbertmann, Cartilha da Grande-Alemanha, Berlim, (1941), p. 16. Mantivemos a ortografia original do opúsculo. 
romanos no ocidente, como os eslavos a oriente. Este lento processo de formação a partir dos "germanos», passando pelos «francos», «saxões», «alamanos» e «bávaros» e depois pelos Estados dos «prússianos», «bávaros», «saxões», «wurtemburgueses», «austríacos» eoutros atéaos «alemãis» actuais encontram-se ainda hoje bem marcado nos múltiplos tipos étnicos do moderno germanismo ${ }^{8}$.

Do que transcrevemos é fácil deduzir que o Germanismo ocorre como um conceito fundacional, flexível no tempo e no espaço, mas considerado seguro fio condutor de um destino manifesto, afinal enunciado de forma não muito diferente de outros menos sujeitos a críticas. $\mathrm{Na}$ verdade, como argumento histórico explicativo das origens alemãs, os Germanos surgem como antepassados comuns, naturalmente indiscutíveis, aceites como tal pela esmagadora maioria dos Reichsdeutschen e dos Volksdeutschen. Quer isto dizer que estes Germanos têm uma função simbólica, unificadora ${ }^{9}$, facilmente compreensível numa nação de história complexa e recente unificação ${ }^{10}$. Dito isto, não é difícil compreender a importância da Arqueologia enquanto instrumento ao serviço da busca de provas científicas, ou como tal consideradas, favoráveis simultaneamente a um conceito alargado do Germanismo, de base difusionista (Fig. 1), inspirado nas teorias de Gustav Kossinna, no qual o factor colonização era de fundamental importância, e a comprovar antecedentes justificativos da expansão territorial alemã. As dificuldades e contingências da investigação arqueológica, sobretudo na área da Pré-História, altamente condicionantes de resultados susceptíveis de possibilitar sínteses coerentes foram, se não eliminadas, pelo menos muito frequentemente ignoradas, pois o processo se desenvolveu inversamente, uma vez que os dados das escavações arqueológicas deviam conformar-se com ideias pré-existentes $^{11}$, sustentando generalizações dificilmente demonstráveis.

8 Herbertmann, p. 19.

9 L. Hedeager, The creation of Germanic identity: A European origin-myth, "Mémoires du Musée de Préhistoire d'Ile de France”, 5, 1993, p. 121-131.

${ }^{10}$ M. Stürmer, O Império Alemão, Lisboa, 2003, p. 3-14, 31-47. É particularmente interessante comparar o texto da Cartilha da Grande-Alemanha, transcrito acima, com o que se pode ler numa obra editada pelo Serviço de Imprensa e Informação do Governo Federal Alemão: K. Römer, A Alemanha dos Nossos Dias, Gütersloh, 1980, p. 22-25. Ambos sublinham a grande antiguidade dos Alemães, aludindo às tribos germânicas de forma muito semelhante.

${ }^{11}$ Ainda que divergente da tese ultradifusionista de Kossinna, a dicotomia proposta por Wahle entre as comunidades que fazem a História (die Geschichten machen) e as que aceitam a História (die Geschichten erleiben), na prática não contraria significativamente a orientação oficial: E. Wahle, Zur ethnischen Dentung frühgeschichtlicher Kulturprovinzen: Grenze der frügeschichtlichen Erkenntnis, I, "Sitzungsberichte der Heidelberger Akademie der Wissenschaften phil.-hist. Klasse”, 1940-1941, 2; J. Malina / Z. Vašíček, Archaeology Yesterday and Today, Cambridge, 1990, p. 105-109. 


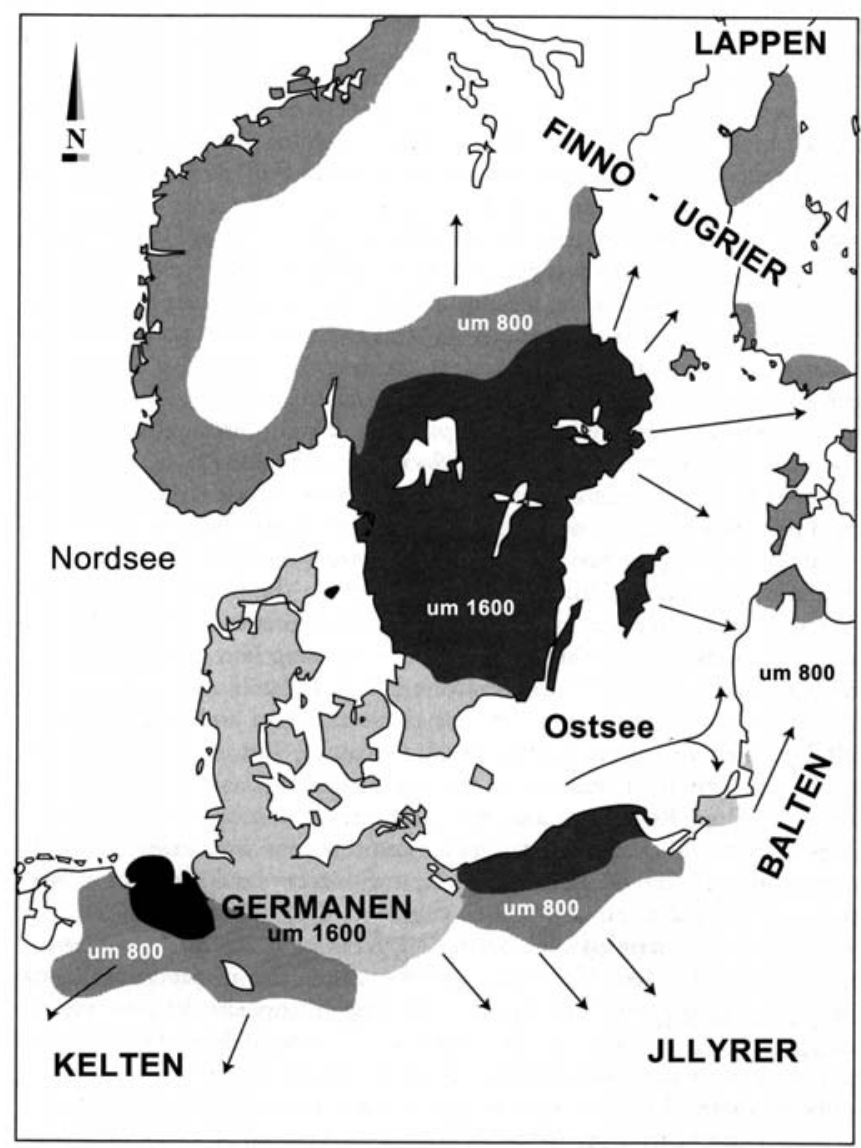

Fig. 1 - O território germânico e a sua expansão durante a Idade do Bronze, segundo Hans Reinerth.

É evidente, como veremos, que este esforço de harmonização ideológica dos resultados da investigação incidiu especialmente sobre as épocas mais directamente relacionadas com a leitura que se pretendia transmitir da origem do povo alemão e com a valorização do aspecto racial, considerado essencial. Por vezes ocorreram situações cuja interpretação se tornou complicada, notando-se na bibliografia da época algum incómodo por parte dos investigadores, confrontados com os limites da pesquisa arqueológica e pressionados pela visão ideológica de um facto histórico. É o caso, por exemplo, no cenário muito valorizado das consequências das grandes vagas de emigração germânicas, do que Hans Zeiss escreveu, em 1934, sobre a raridade de testemunhos da 
presença visigótica na Península Ibérica: Se tivéssemos que contar apenas com a arqueologia nunca poderíamos crer que a Espanha foi governada por Germanos no século sétimo ${ }^{12}$. Esta simples frase põe em relevo as ambiguidades da prática arqueológica, tanto como o estado da investigação na época, circunstâncias que não foram ignoradas no processo de interpretação do passado germânico pelos ideólogos do III Reich, por vezes de forma muito elaborada. Esta manipulação da História, neste caso largamente apoiada na Arqueologia, não é exclusiva do regime nacional-socialista, uma vez que a podemos encontrar noutros contextos, embora os regimes totalitários se distingam, como é evidente, na criação de imaginários exaltantes, factores de identidade e motores de uma dinâmica de incondicional aceitação de uma ordem visando objectivos em larga medida utópicos.

O condicionamento histórico-político das massas conseguia-se facilmente, numa época em que a palavra impressa e, de forma crescente, a rádio e o cinema, constituíam elementos fundamentais da circulação de ideias ${ }^{13}$, através de um processo combinando censura e divulgação em larga escala, actuando em dois planos distintos, um relacionado com a produção de ideias, filtrando-as drasticamente, outro com a difusão dos conceitos que interessava inculcar na comunidade. Embora se trate de textos literários, muito datados, o que Huxley e Orwell escreveram sobre a manipulação da História, que pode ir até à falsificação pura e simples de determinados factos ${ }^{14}$, é uma demonstração eloquente do funcionamento dos mecanismos de condicionamento da opinião e, consequentemente, dos comportamentos sociais. O primeiro destes autores retomou o tema numa obra menos conhecida, publicada nos finais dos anos 50, na qual analisa o que se passou, antecipando o que poderá vir a acontecer numa sociedade tecnológica, deixando-nos na última página um alerta esclarecedor: Osmétodos empregados pelos educadores clássicos eram, esão ainda, extremamente ineficazes. Sob a férula de um ditador científico, a educação produzirá verdadeiramente os efeitos desejados e dai resultará que a maior parte dos homens e das mulheres chegarão a amar a sua servidão sem nunca pensarem na revolução.

${ }^{12}$ H. Zeiss, Die Grabfunde aus dem spanischen Westgotenreich, Berlim, 1934, p. 142.

${ }^{13}$ Lembramos, a este propósito, o que Carcopino escreveu em 1938 e o que Albert Speer descreveu no seu julgamento em Nuremberga, em 1946: J. Carcopino, A Vida em Roma no Apogeu do Império, Lisboa, s/d, p. 7-9; A. Huxley, Regresso ao Admirável Mundo Novo, Lisboa, s/d, p. 87-89 (= Huxley, Regresso).

${ }^{14}$ Huxley, Regresso, p. 15-22. Para além das múltiplas obras políticas que se ocupam deste tema destacamos, para a História Contemporânea, os interessantes trabalhos de Marc Ferro, que aludem com frequência à falsificação de fontes documentais: M. Ferro, Falsificações da História, Lisboa, s/d; Cinema e História, Rio de Janeiro, 1992. 
Parece que não há nenhuma razão válida para que uma ditadura perfeitamente cientifica seja alguma vez derrubada ${ }^{15}$.

Numa sociedade de massas como a do III Reich, o passado reformulado reflecte-se num conjunto de atitudes simbólicas, rigorosamente coordenadas e estabelecidas sobre um programa científico oficial, de larguíssima difusão, ao serviço de uma interpretação racial da História, facilmente aceite pela maioria da população alemã, atendendo ao ambiente político instaurado, aos êxitos alcançados pelo regime e aos métodos empregues pelos responsáveis ${ }^{16}$, com largo recurso à colaboração de intelectuais e cientistas (Fig. 2). Por exemplo, a Editora Nordland, fundada em 1934 por F. Sorensen em Magdeburgo e directamente dependente das SS, contava com um catálogo de duzentas e cinquenta obras, algumas das quais, de temática racial e histórica, ultrapassaram

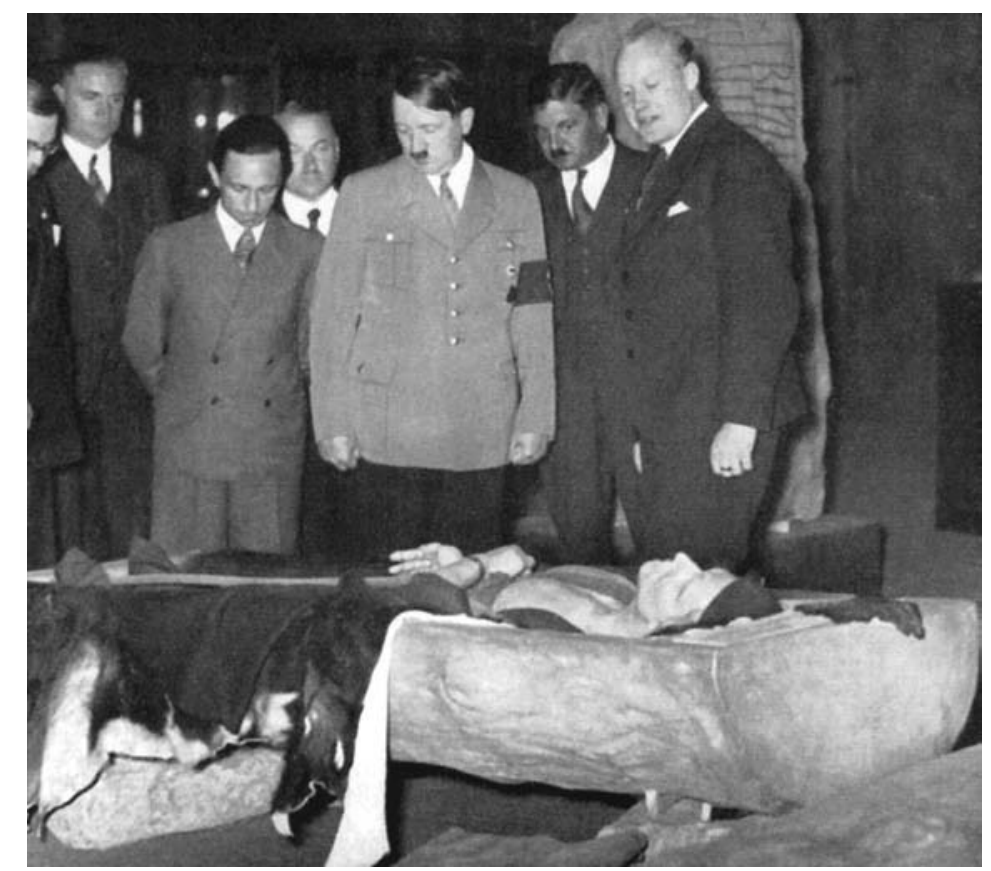

Fig. 2 - Hitler e Goebbels admiram uma reconstituição arqueológica na Exposição Deutsches Volk-Deutsche Arbeit, realizada em Berlim em 1934.

${ }^{15}$ Huxley, Regresso, p. 244-245.

${ }^{16}$ Römer, p. 39-42. 
tiragens superiores a várias centenas de milhar, como Unser Glaube, de G. Griesmayr, onde se nega a imortalidade sob qualquer forma a não ser biológica ${ }^{17}$. Para melhor compreensão do que o Nacional-Socialismo pretendia neste aspecto citamos o que Adolf Hitler entendia como finalidade do ensino da História: Principalmente no ensino da história é que se deve tomar em consideração uma reeducação nos programas. A parte mais importante é o conhecimento das linhas gerais da evolução. Quanto mais se restringir o ensino a esse ponto de vista, tanto mais é de esperar que os indivíduos tirem proveito dos seus conhecimentos, o que é também vantagem para a colectividade. Não se estuda história somente para saber o que aconteceu, mas para que ela possa orientar o futuro da nação. Essa é a finalidade, o ensino da história apenas um meio ${ }^{18}$. Quanto à função da ciência, Hitler não foi menos claro quando escreveu o seguinte: O Estado racista deve ver na ciência um meio de aumentar o orgulho nacional. Tanto a história universal como a história da civilização devem ser ensinadas sob esse aspecto. Um inventor deve ser visto não só porque é inventor, mas também porque é um dos nossos compatriotas ${ }^{19}$.

O que fica dito resume perfeitamente os meios através dos quais se procurava atingir o que Hitler designava como um fanático entusiasmo nacional e Aldous Huxley apelidava de veneno gregário ${ }^{20}$, procurando a fusão do indivíduo na massa ao serviço dos grandes objectivos do Estado. A elaboração de uma história destinada ao homem comum, na qual a colonização alemã dos territórios a Leste surge como um ponto fulcral no discurso do Lebensraum, desenvolve-se como consequência lógica de um pensamento político cujas preocupações ultrapassavam largamente a questão da simpes recuperação das fronteiras anteriores ao Tratado de Versalhes, mas sim um grande espaço germânico. Nesta mesma linha preocupada com a ratio território-população foi interpretada a expansão germânica pelas províncias romanas, entendida como consequência do crescimento demográfico e de uma natural e perene necessidade de novos territórios, expansão cujo resultado mais significativo e prestigioso consistiu na criação do Império Carolíngio, origem do I Reich.

Para além de todos os progressos da investigação histórica, a verdade é que a acção das tribos germânicas na destruição do Império Romano do Ocidente, considerada, consoante as épocas, mais ou menos determinante ${ }^{21}$, pouco perdeu

${ }^{17}$ G. Griesmayr, Unser Glaube, Berlim, 1941; H. Landemer, As Waffen S.S., Lisboa, 1974, p. 58.

18 A. Hitler, A Minha Luta. Mein Kampf, Lisboa, 1976, p. 308.

${ }^{19}$ Hitler, p. 311.

${ }^{20}$ Huxley, Regresso, p. 87-101.

${ }^{21}$ B. Ward-Perkins, A Queda de Roma e o Fim da Civilização, Lisboa, 2005, p. 9-22. 
do valor simbólico que o público não especialista lhe atribuía décadas atrás, quando os Aliados designavam pejorativamente os Alemães como Hunos ou como, mais recentemente, numa das últimas cenas do filme A Queda do Império Romano, os prisioneiros germânicos supliciados no Forum Romanum vaticinam, invocando Wotan, a destruição de Roma ${ }^{22}$. Embora a queda do Império do Ocidente demorasse ainda quase três séculos e a suas causas continuem a ser discutidas, foi este tipo de lugares comuns da ficção histórica, perdoe-se-nos a contradição, que se instalaram na narrativa oficial germânica promovida pelo III Reich, uma história exemplar para uso político. Tal como os indivíduos, em circunstâncias especiais, não hesitam em recriar o passado, moldando-o aos seus interesses ou necessidades do momento, assim acontece também com as nações, através da acção dos seus dirigentes, fenómeno que não se limitou à Alemanha nacional-socialista, encontrando-se hoje activo em muitas regiões do globo, particularmente na Europa ${ }^{23}$.

Colocando a Arqueologia ao serviço da ideologia estatal, os nacionais-socialistas incorporaram elementos científicos no seu discurso teórico, sujeitando-os, naturalmente, aos fins definidos desde 1924 por Adolf Hitler. Foi uma opção coerente e inteligente, que considerou as debilidades da pesquisa arqueológica do primeiro terço do século XX e que contou com a dedicação de investigadores de nomeada, devidamente apoiados. Compreenderemos melhor o ambiente em que se processou a investigação arqueológica entre 1933 e 1945 , sobretudo aquela que, de alguma forma se relacionava com o passado germânico, lembrando uma pertinente passagem do escritor Ernst Jünger, no seu romance Sobre as Falésias de Mármore, no qual muitos comentadores pretendem ver uma alegoria ao regime nacional-socialista, passagem que consideramos uma alusão directa à forma como a investigação histórica e arqueológica se processavam na Alemanha de 1939, ano da redacção da obra, cuja matéria não deixou de suscitar algumas preocupações ao autor. Eis o que Jünger diz de uma das personagens centrais do livro, Braquemart: Ele era de opinião que existiam na terra, desde o princípio, duas raças - os senhores e os escravos -, e que com o correr dos tempos se registara entre elas um cruzamento. Era, a este respeito, um discípulo do Velho Amotinador e reclamava, a exemplo do mestre, a nova separação. Como todo o teórico grosseiro, alimentava-se também daquilo que a ciência oferecia de menos intemporal, praticando em

${ }^{22}$ V. Mantas, Imaginário e imagens. A civilização romana através do peplum, "Som e Imagem no Ensino das Línguas Clássicas”, Coimbra, 2003, p. 180-182.

${ }^{23}$ M. Rowlands, The politics of identity in archaeology, "Social Construction of the Past. Representation and Power”, Londres, 1994, p. 129-143; Jones, p. 135-144. 
especial a arqueologia. Não era suficientemente perspicaz para suspeitar de que a nossa pá põe infalivelmente a descoberto aquelas coisas que nos vivem na mente, pelo que, como já muitos outros antes dele, julgava ter descoberto a sede primitiva do género humano [...]. Ele pertencia à raça dos sonhadores concretos, que é extremamente perigosa ${ }^{24}$.

A formidável máquina de propaganda alemã não esquecia a importância da investigação arqueológica como elemento de prestígio internacional, independentemente das interpretações que a partir dela se poderiam desenvolver. Tomemos o exemplo, mais uma vez, da Cartilha da Grande-Alemanha, na qual a Arqueologia teve direito a um longo parágrafo, aliás merecido: A ciência alemã está sempre activa mesmo fora do território do Reich. Viagens de investigação à África, Ásia Oriental e às regiões polares assim como expedições oceanográficas são, desde o século XIX, um fecundo campo de actividade para os sábios alemãis. De entre os vivos é mundialmente conhecido, como investigador do Tibet, Wilhelm Filchner. Têm grande importância as excavações de arqueólogos alemãis, principiando por Haller (Grécia) e passando por Lépsius (Egito) até à grande obra de Schliemann que descobriu e excavou a antiga Troia. A desenterração de Olímpia efectuada até aos nossos dias é também devida à iniciativa e auxílio do Govêrno alemão - de acôrdo com o Govêrno grego. Ainda há pouco tempo foi possivel descobrir, por meio de métodos modernos de fotografia aérea, o grande Carnuntum, próximo de Viena, um verdadeiro Chicago da remota antiguidade ${ }^{25}$.

Ainda que muito geral, a referência à actividade arqueológica neste contexto é muito significativa, merecendo especial atenção o apontamento sobre a fotografia aérea com fins arqueológicos, cujo largo uso na Alemanha justificou a designação de Arqueologia Aérea para este eficiente instrumento de pesquisa, desenvolvido a partir de vôos de reconhecimento militar na I Guerra Mundial e que, no final dos anos trinta, atingira notável qualidade na Alemanha, conduzindo, inclusive, a projectos de colaboração com arqueólogos ingleses ${ }^{26}$. De passagem, lembramos também a excelente qualidade da ilustração de muitos trabalhos publicados pelos arqueólogos alemães entre 1933 e 1945 , verificando-se um notável progresso nas técnicas do desenho arqueológico,

${ }^{24}$ E. Jünger, Sobre as Falésias de Mármore, Lisboa, 1995, p. 145-146.

${ }^{25}$ Herbertmann, p. 39.

${ }^{26}$ A colaboração anglo-germânica contou com a participação de um dos pioneiros da aerofoto-interpretação britânica, O. G. S. Crawford, e reflecte o ambiente favorável à situação alemã que caracterizou largos sectores da sociedade inglesa nos finais da década de 30 . O termo Arqueologia Aérea foi utilizado por Paul Karlson em 1941, num artigo da revista "Der Adler", publicada pela Força Aérea Alemã. 
nomeadamente a nível das reconstituições, como, por exemplo, nos trabalhos de Wilhelm Petersen ${ }^{27}$, distinguido em 1936 com o Grande Prémio da Reichbund für Deutsche Vorgeschichte, uma das organizações dependentes do ideólogo nacional-socialista Alfred Rosenberg.

A aceitação pública da reconfiguração da História através dos dados arqueológicos, sobretudo exercida em relação ao período pré-histórico, desde logo considerado parte integrante da história do povo alemão, foi muito grande, por duas razões facilmente compreensíveis, uma resultante do desconhecimento da matéria pela maioria dos receptores, outra como consequência do enorme esforço de divulgação das doutrinas oficiais. A estes dois factores podemos acrescentar o efeito causado pelo ambiente de exaltação em que o regime mergulhou os alemães a partir de 1933, e que levou a uma espécie de euforia, muito natural após as humilhações que acompanharam o Tratado de Versalhes e o desfilar de misérias da depressão que acompanhou o conturbado período de Weimar, marcado pela inflação e pelo desemprego exorbitantes, situação que levou muitos alemães a aderirem com entusiasmo ao Nacional-Socialismo ${ }^{28}$.

O fenómeno não pode compreender-se plenamente se não tivermos em conta o aspecto social que o envolve desde o início, neste caso particularmente relevante. Com efeito, como noutros países ${ }^{29}$, grande parte dos arqueólogos alemães da época pertencia à classe média, muito castigada pelas consequências da crise, ou a níveis superiores da sociedade, ressentidos com as sanções impostas pelos Aliados à Alemanha, nomeadamente no aspecto territorial. Assim, não é difícil compreender que muitos deles se tenham tornado, por via do patriotismo prático ou idealista, propagandistas comprometidos e activamente empenhados na defesa e difusão da visão oficial do Germanismo, decorrente do conceito de Kulturkreis. É claro que, como sempre acontece, o grupo mais numeroso foi constituído por colaboradores mais ou menos passivos, o dos Mitläufer, predominante no conjunto da população alemã ${ }^{30}$. Resta saber se os opositores activos à linha imposta ou sugerida pelo Estado, excluíndo os que foram afastados por razões raciais ou assim consideradas, como foi o caso de Gerhard Bersu, responsável pela Römischen Germanische Komission até 1935 e notável crítico

${ }^{27}$ Sobre a obra deste polifacetado artista: U. Christiansen / H.-C. Petersen, Wilhelm Petersen. Der Maler des Nordens, Tübingen, 1993.

${ }^{28}$ G. Prien, A Caminho de Scapa Flow, Lisboa, 1941, p. 111-117.

${ }^{29}$ B. Taylor, Amateurs, professionals and the knowledge of archaeology, "The British Journal of Sociology", vol. 46, 3, 1995, p. 499-509.

${ }^{30}$ B. Arnold, The past as propaganda: totalitarian archaeology in Nazi Germany, "Antiquity”, 64, 1990, p. 472 (=Arnold, Past). Este artigo de Betina Arnold constitui uma valiosa síntese, imparcial e bem documentada, sobre o tema que aqui tratamos. 
das ideias oficiai ${ }^{31}$, terão agido sempre por razões de ordem científica e se o seu número atingiu a percentagem de inconformistas que Goebbels considerava existir em todas as sociedades ${ }^{32}$.

Outro factor que contribuiu fortemente para a utilização ideológica da Arqueologia na Alemanha nacional-socialista, em especial no campo da Pré-História, e do indiscutível apoio que muitos especialistas prestaram ao novo regime, foi a muito limitada importância atribuída à Pré-História enquanto matéria académica e científica na Alemanha do início do século XX. Com efeito, só em 1928 foi criada em Marburgo (Hesse) a primeira cátedra universitária da disciplina, mantendo-se o ensino a um nível inferior ao que era praticado em relação aos Estudos Orientais e à Arqueologia e História do mundo clássico, matérias altamente prestigiadas e apoiadas dentro e fora das universidades ${ }^{33}$. Esta dicotomia entre Pré-História e Arqueologia, em especial Arqueologia Clássica, pode explicar-se como uma consequência da importância da formação humanística herdada do século XIX, fortíssima logo no Ensino Secundário e, naturalmente, continuada na tradição e à sombra do tremendo prestígio atingido por figuras como Theodor Mommsen. Não esqueçamos que a Escola Alemã considera fundador da Arqueologia Clássica, como disciplina científica, o não menos conhecido J. J. Winckelmann, como tal festejado anualmente pelo Instituto Arqueológico Alemão, em Roma. O Kaiser Guilherme II demonstrou algum interesse pela Pré-História, mas as suas atenções incidiram principalmente no mundo clássico, apoiando escavações de grande envergadura no grande santuário romano de Baalbek, no Líbano, entre outras, e acompanhando estudos arqueológicos realizados no Limes germânico, onde numa ocasião

${ }^{31}$ K. Sklenar, Archaeology in Central Europe: the first 500 years, Nova Iorque, 1983, p. 160. Bersu expatriou-se para Inglaterra, onde escavou, no final dos anos 30, o importante sítio pré-histórico de Woodbury: C. Evans, Archaeology and modern times: Bersu's Woodbury 1938-1939, “Antiquity”, 63, 1989, p. 436-450.

${ }^{32} \mathrm{Na}$ medida do possível, e essa margem de discordância era muito reduzida, houve, como vimos a propósito de Wahle, tentativas de desenvolver trabalho teórico não condicionado pela linha oficial, sem que tal facto significasse verdadeira oposição ao regime. Goebbels considerava que os opositores políticos activos não representam, em média, mais de $7 \%$ do total da população envolvida. A abertura progressiva dos arquivos existentes permite hoje uma ideia mais correcta do que se passou entre 1933 e 1945, sem que o quadro geral sofra significativas alterações. M. Maischberger, German archaeology during the Third Reich, 1933-45: a case study based on archival evidence, "Antiquity”, 76, 2002, p. 209-218; K. Junker, Research under dictatorship: the German Archaeological Institute 1929-1945, “Antiquity”, 72, 1998, p. 282-292.

${ }_{33}$ Arnold, Past, p. 467-468. 
quase foi vitimado pela demonstração falhada do funcionamento de uma balista romana ${ }^{34}$.

A ciência da Pré-História conheceu, como se pode deduzir, inícios difíceis e vegetou longamente por falta de verbas e de uma estrutura académica adequada, conhecendo os pré-historiadores uma posição subalterna em relação aos seus colegas de áreas nitidamente menos ou nada relacionadas com o passado do território alemão ${ }^{35}$. Esta circunstância, conhecidas as rivalidades, interesses de grupo e questiúnculas que enxameiam a investigação arqueológica, explica, pelo menos em parte, o que se passou depois de 1933. Na verdade, a ascenção da Pré-História na Alemanha pode considerar-se um resultado directo da política nacional-socialistas, para não dizer mais, uma vez que, não só as condições materiais com que os arqueólogos se debateram até 1933 se alteraram radicalmente como, a nível académico, foram criadas condições ideais para o desenvolvimento de carreiras e ocupação de cargos de prestígio, antes impensáveis. Para apreendermos rapidamente o alcance das medidas desenvolvidas pelo regime basta recordar que, entre 1933 e 1935, foram criadas oito novas cátedras universitárias de Pré-História, o que permitiu uma enorme movimentação no meio académico e multiplicar os trabalhos arqueológicos ${ }^{36}$, progressos compensados por uma filosofia de legitimação da ideologia nacional-socialista quanto aos aspectos raciais e territoriais, na linha defendida, por exemplo, na obra Geist und Blut, do arqueólogo austríaco Oswald Menghin, que atingiu posição destacada na arqueologia do Reich ${ }^{37}$.

A importância crescente de um grupo de arqueólogos e de historiadores preocupados com a afirmação de uma ideia de continuidade étnica do povo alemão a partir de raízes antiquíssimas e de uma dinâmica territorial complexa, interpretada à luz de um pensamento em que se combinavam romantismo e Realpolitik, levou à valorização de alguns aspectos específicos do passado germânico conhecidos através das fontes clássicas, caso do célebre episódio da derrota romana por Arminius e da descrição das tribos germânicas por Tácito. No primeiro caso, o chefe da tribo dos Queruscos, que massacrou três legiões romanas na floresta de Teutoburg, no ano 9, foi, tal como Viriato ou Vercingétorix, considerado um herói nacional, daí a denominação de primeiro

${ }^{34}$ A. Wilkins, Roman Artillery, Princes Risborough, 2003, p. 24. Sobre as escavações em Baalbek, que Guilherme II visitou em 1897, consultar a obra de Theodor Wiegand, notabílissimo arqueólogo, pioneiro da fotografia aérea alemã: Th. Wiegand, Baalbek, I-II, Berlim, 1921.

${ }^{35}$ J. Collis, Celts and politics, "Cultural Identity and Archaeology. The Construction of European Communities”, Londres, 1996, p. 174.

${ }^{36}$ Arnold, Past, p. 467-468.

${ }^{37}$ O. Menghin, Geist und Blut, Viena, 1934. 
alemão com que foi distinguido (Fig. 3). Esta interpretação de um episódio específico, mas que pesou indiscutivelmente na decisão romana de suspender a expansão territorial na Germânia $^{38}$, não foi excepcional, nem deve ser considerada característica dos regimes nacionalistas autoritários. Lembramos, a propósito deste tipo de interpretações histórico-políticas, o que se passou em relação ao episódio gaulês de Bibracte e ao enorme investimento num projecto de escavação do Mont-Beuvray, patrocinado pelo presidente Miterrand, que considerou ser esse o cenário do primeiro acto da história frances $a^{39}$. Quanto à Germania, de Tácito, cuja redacção obedeceu seguramente a preocupações de filosofia política que ultrapassavam a intenção descritiva, foi considerada uma obra tendenciosa, prejudicial à imagem dos Germanos, que Tácito descreveu

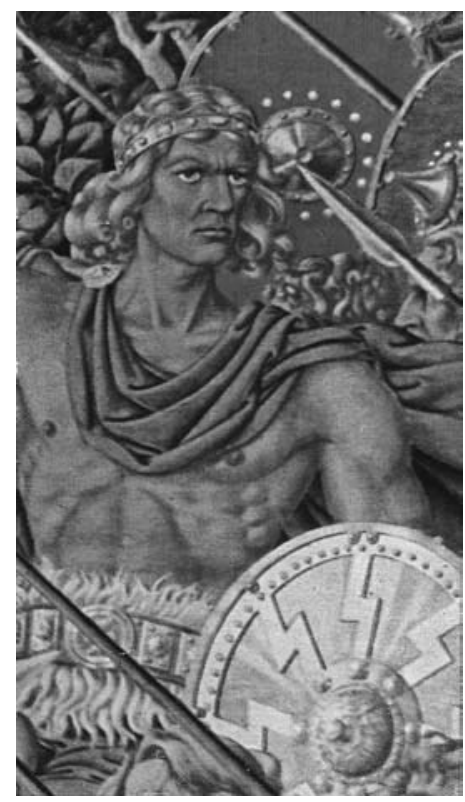

Fig. 3 - O chefe querusco Arminius (Hermann) numa tapeçaria de Werner Peiner destinada à Nova Chancelaria. Notar a insígnia rúnica dos SS na decoração do escudo.

${ }^{38}$ D. Timpe, Arminius. Studien, Heidelberga, 1970; P. Petit, Histoire Générale de l'Empire Romain, I, Paris, 1974, p. 43-44.

${ }^{39}$ B. Fleury-Ilett, The identity of France, "Cultural Identity and Archaeology. The Construction of European Communities”, Londres, 1996, p. 196, 203-206; C. Breton, Six années de recherche européenne au Mont Beuvray, “Archéologia”, 380, 2001, p. 20-25. 
como uma espécie de bons selvagens, o que não interessava, naturalmente, ao que a orientação nacional-socialista pretendia transmitir como cultura dos antigos camponeses germânicos altamente desenvolvida. Na obra de Tácito, todavia, existe um ponto que foi salvaguardado, por se adequar à política reinvindicativa relacionada com a Ostmark, o qual consiste na clara localização de tribos germânicas a leste do Vístula, pelo menos até ao Rio Passarge (Pasleka), o que a investigação moderna não contraria ${ }^{40}$.

O desenvolvimento da investigação pré-histórica centrada no passado do território alemão seguiu princípios que, objectivamente, não podem ser considerados muito diferentes dos que hoje observam os defensores de um Celtismo a que se atribui a origem da Europa, considerando os Celtas como os primeiros europeus ou os pais da Europa ${ }^{41}$. A orientação fortemente politizada da investigação arqueológica levou a que se estabelecesse uma fractura entre arqueólogos pré-historiadores e arqueólogos clássicos, sobretudo no tocante aos que continuavam a investigação sobre o período romano na Alemanha, considerados pouco patrióticos e designados de forma algo pejorativa como Römlinge $e^{42}$, situação que não pode isolar-se do estado geral da arqueologia alemã anterior a 1933. Por esta razão, o Römisch Germanisches Zentral Muzeum in Mainz passou a designar-se, muito apropriadamente, Zentral Muzeum für Deutsche Vor- und Frügeschichte, em 1939, enquanto muitas publicações especializadas mudavam também de nome ${ }^{43}$. Tal facto não significa que a História e a Arqueologia do mundo greco-romano fossem pura e simplesmente ostracizadas, sobretudo fora da Alemanha, o que, de alguma forma, constituía uma contradição, como acontecia com frequência na aplicação da doutrina nacional-socialista, ainda que, neste caso, a contradição talvez fosse mais aparente que real.

Um escritor português conhecido pelos seus relatos de viagem publicados entre as duas guerras mundiais, Carlos Santos, reflecte, no seu livro Como eu vi a Alemanha esta atmosfera germanizante do passado histórico mais remoto ao

40 Tácito, A Germânia, (Trad. A. C. Monteiro), "Cadernos Culturais Inquérito", 64, Lisboa, s/d; B. Arnold, The past as propaganda, "Archaeology", vol. 45, 4, 1992, p. 33 (=Arnold, Propaganda); A. Bursche, Archaeological sources as ethnical evidence. The case of the Eastern Vistula Mouth, "Cultural Identity and Archaeology. The Construction of European Communities", Londres, 1996, p. 228-234.

${ }^{41}$ Fitzpatrick, p. 250-251. A questão do Celtismo, pelas suas evidentes implicações políticas contemporâneas, merece urgente atenção, considerando a forma abusiva como o conceito ocorre, cada vez com maior frequência.

${ }^{42}$ K. Jacob-Friesen, Wissenschaft und Weltanschauung in der Urgeschichtsforschung, "Die Kunde", N.F., 1-2, 1950, p. 4.

${ }^{43}$ Arnold, Past, p. 466-467. 
referir-se às ruínas romanas de Trier de forma esclarecedora, como algo alheio e quase repulsivo ao verdadeiro espírito alemão: Ao contemplar este monumento (o anfiteatro) único no vasto quadro da cultura alemã, deu-me a impressão de que a Alemanha deve senti-lo no seu seio como nós sentimos no estômago um fruto verde ou um peixe pôdre, que não se digere-deve ter vontade de vomitar. Eu cá, minhas Senhoras e meus Senhores, se fosse alemão, propunha à França a troca de Tréveris e um pouco mais do vale do Mosela por Estrasburgo e um naco da Alsácia. Até os nomes facilitavam a troca: Strasbourg, mesmo em francês, é sempre um nome alemão ${ }^{44}$. Talvez seja pertinente notar que o autor manifesta clara simpatia pelo Nacional-Socialismo, tanto como anos antes mostrara nítido desagrado pelo regime fascista italiano ${ }^{45}$.

Hitler mostrou sempre grande interesse pela civilização greco-romana, tanto mais que considerava os Gregos como descendentes de tribos germânicas estabelecidas na Hélade no Neolítico, na linha do hiperdifusionismo e migracionismo defendido nas teses de Gustav Kossinna, que o arqueólogo Hans Reinerth e a sua equipa julgaram poder confirmar através de escavações na Grécia ${ }^{46}$. A ideia de fundamentar na acção de elementos indoeuropeus, arianos, a origem das grandes civilizações mediterrânicas (Fig. 4), embora fantasista para um período tão recuado, não deixa de ganhar alguma credibilidade para a Idade do Bronze, uma vez que os Micénicos, evidentemente indoeuropeus, serão nórdicos, oriundos das margens do Báltico ${ }^{47}$. Logo em 1924, Hitler chamou a atenção para o valor da Antiguidade Clássica nos seguintes termos: Não se deve afastar o estudo da história antiga, pois a história romana, bem apreciada nas suas linhas gerais, é e será sempre a melhor mestra não só para o presente como para o futuro. O ideal da cultura helénica, na sua típica beleza, deve ser aproveitado. Não se deve destruir a grande comunidade racial pelas diferenciações entre os vários povos. A luta que hoje se agita tem o grande objectivo de, ligando a sua existência ao passado milenar, unificar o mundo greco-romano com o germânico ${ }^{48}$.

Esta admiração pela Antiguidade Clássica demonstrada por Hitler reflectia quer a preocupação ideológica de conseguir a fusão do Germanismo com o Classicismo, quer a sua própria sensibilidade estética, e teve evidente

${ }^{44}$ C. Santos, Como eu vi a Alemanha, Lisboa, 1935, p. 387-388.

${ }^{45}$ C. Santos, Como eu vi a Itália, Lisboa, (1928), p. 46-51, 264-266.

${ }^{46}$ H. Picker, Hitler's Tischgespräche im Führer Hauptquartier, Estugarda, 1976, p. 96; Arnold, Past, p. 467.

${ }^{47}$ M. H. Rocha Pereira, Estudos de História da Cultura Clássica, I, Cultura Grega, Lisboa, 1993, p. 31-44.

${ }^{48}$ Hitler, p. 309. 


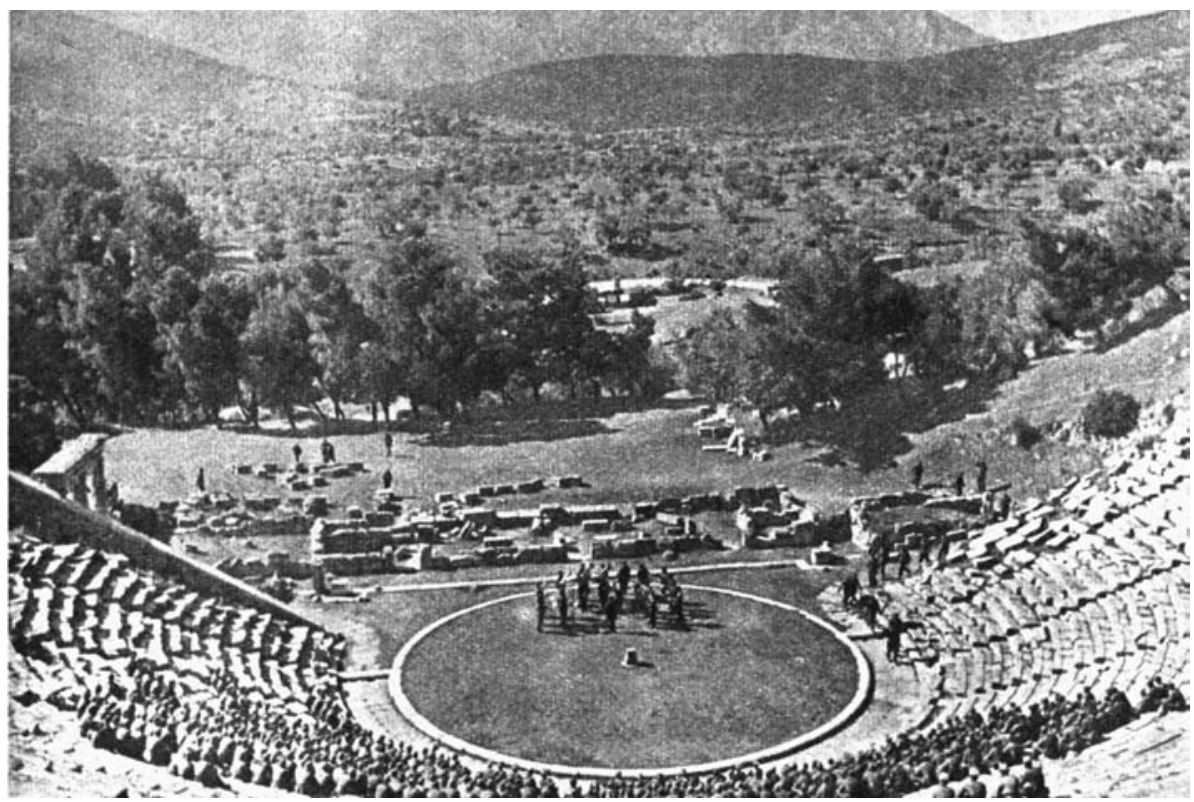

Fig. 4 - Soldados alemães assistem a um espectáculo no teatro de Epidauro, em 1941

(Signal, PK Baier).

consagração em muitas das expressões simbólicas do regime nacional-socialista, seja a nível das insígnias ou da arquitectura monumental ${ }^{49}$. Um testemunho claro do valor atribuído pelo regime, e muito especialmente por Hitler, aos estudos consagrados ao mundo greco-romano, consiste na atribuição da prestigiosa distinção que era a Adlerschild, destinada a galardoar figuras particularmente importantes da sociedade alemã, logo em 1933 e 1934, a três justamente famosos investigadores do período clássico: Eduard Schwartz, filólogo e historiador, Wilhelm Dörpfeld, arquitecto e arqueólogo, e Theodor Wiegand, arqueólogo (Fig. 5), todos amplamente merecedores desta elevada honraria ${ }^{50}$.

${ }^{49}$ A águia, a cruz suástica e os símbolos rúnicos constituem a parte fundamental deste discurso visual, a que poderemos juntar os estandartes e a saudação de inspiração romana. Alguns objectos arqueológicos foram utilizados como modelos para emblemas de lapela, como é o caso dos machados que identificaram os contribuintes para a colecta do Socorro de Inverno (Winterhilfswerk), em 1940-1941. Sobre a arquitectura: A. Speer (Org.), Moderna Arquitectura Alemã. Catálogo de Exposição, Lisboa, 1941; R. Taylor, Word in Stone. The Role of Architecture in the National Socialist Ideology, Berkeley, 1974.

${ }^{50}$ Entre 1933 e 1944, último ano de que se conservaram os registos, foi atribuído um total confirmado de trinta e oito distinções, abrangendo individualidades de áreas muito diversas, não se encontrando mais arqueólogos representados além de Dörpfeld e de Wiegand, o último dos 


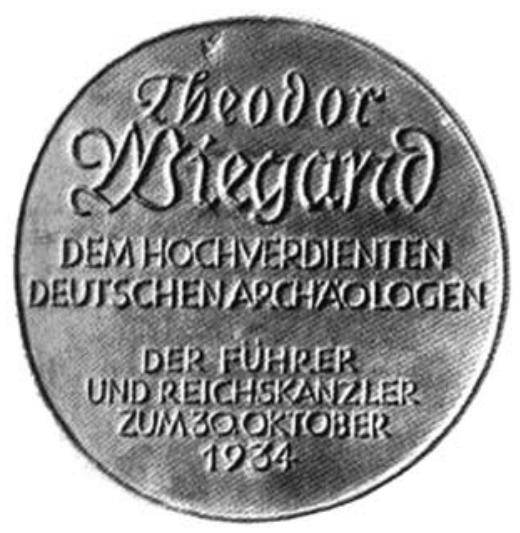

Fig. 5 - Reverso da medalha Adlerschild concedida em 1934 a Theodor Wiegand.

As ideias sobre as quais se desenvolveu o essencial da doutrina nacional-socialista não constituiram novidades, tendo sido desenvolvidas, quer no campo racial, quer no campo histórico, antes da redacção do Mein Kampf hitleriano. Germanismo e Celtismo constituiram, antes da I Guerra Mundial, áreas de forte presença na literatura histórica ou pretensamente histórica, merecendo especial simpatia e aceitação por parte do público leitor da época. Mesmo em Portugal não faltaram os defensores de uma visão purista do Celtismo, divulgada em livrinhos populares, como os da Biblioteca do Povo e das Escolas, onde encontramos um, de autor anónimo, intitulado As Raças Históricas da Lusitânia ${ }^{51}$. O interesse pelas coisas celtas tornou-se mesmo uma mania entre os círculos letrados da época, merecendo uma acutilante observação de Virgínia Woolf, ainda que indirecta: Não acredito que todas as marcas circulares existentes nos campos de Inglaterra tenham sido acampamentos. Os antiquários a tudo chamam «acampamento». Estou sempre a perguntar-lhes: «Sendo assim, onde é que acham que os nossos antepassados guardavam o gado?». Metade dos acampamentos existentes em Inglaterra não passam de velhos currais ${ }^{52}$.

quais fora já distinguido, em 1931, com a prestigiada condecoração Pour le Mérite. A Adlerschild foi criada no período de Weimar, sendo concedida em nome do Chanceler e, depois, do Führer, que entregava o prémio pessoalmente, quando possível: M. Gibbs, The eagle shield of Germany, www.axishistory.com (2006).

${ }^{51}$ As Raças Históricas da Lusitânia, "Biblioteca do Povo e das Escolas", Lisboa, 1882. Nesta mesma colecção, Leite de Vasconcelos defendeu a continuidade histórica entre Lusitanos e Portugueses: J. L. Vasconcelos, Portugal Pré-Histórico, Lisboa, 1885, p. 4.

${ }^{52}$ V. Woolf, A Viagem, Lisboa, 1995, p. 139. 
Voltando ao Germanismo, eis o que o professor universitário F. Dahn escreveu na História Universal coordenada por Guilherme Oncken, traduzida e publicada em Portugal nas vésperas da Grande Guerra: Do que fica dito, se deduz que os Germanos ao entrarem na história já se não achavam no estado selvagem, a natureza tinha ido pródiga com eles dotando-os nobre e profusamente. Achavam-se em um periodo de civilização muito rudimentar, em uma espécie de periodo preparatório da civilização comparado com o desenvolvimento posterior, porém não em um periodo desprovido de toda a cultura. O seu grau de civilização pode comparar-se com o que apresentavam os antigos gregos das poesias de Homero ${ }^{53}$.

Este tipo de discurso, simultaneamente cauteloso e encomiástico, encontrará pleno desenvolvimento sob a égide de alguns ideólogos do III Reich, abandonada a tónica defensiva que se nota no texto de Dahn. Quer isto dizer que no início do século XX existia uma especial predisposição para aceitar reconfigurações do passado segundo ideias mais ou menos românticas, habilmente utilizadas, aqui e ali, pelas forças políticas em oposição na Europa, através de uma popularização que podemos comparar à moda do multiculturalismo folclórico que se instalou no mundo dos nossos dias ao serviço da globalização. Na Alemanha ganhou força o termo Urgeschichte para designar o período pré-histórico, entendido como directamente relacionado com o passado histórico alemão, subentendendo claramente um conceito de continuidade, uma continuidade que admitia alterações territoriais, fluxos e refluxos, mas que valorizava, acima de tudo, a transmissão inalterada do sangue germânico.

O mentor principal desta teoria da continuidade absoluta foi Gustav Kossinna (Fig. 6). Kossinna faleceu um ano antes da subida de Hitler ao poder, tendo reeditado em 1921 uma obra fundamental para o processo de reinterpretação nacional-socialista da Pré-História, intitulada Die Deutsche Vorgeschichte: eine Hervorragend Nationale Wissenschaft ${ }^{54}$. Nela, Kossinna definiu a Pré-História como uma disciplina preeminentemente nacional, como reza o título, não deixando a dedicatória ao povo alemão quaisquer dúvidas quanto à intenção abertamente nacionalista do autor. Aliás, esta característica do temperamento e da obra de Kossinna, um intelectual mergulhado na atmosfera do seu tempo e susceptível à tragédia que representou o fim do II Reich, revelou-se cedo. Em 1919 redigiu um artigo, que enviou aos delegados da Conferência de Paz de Versalhes, sem que

${ }^{53}$ F. Dahn, História primitiva dos povos germânicos e romanos, "História Universal de Guilherme Oncken", VI, Lisboa, s/d, p. 34

${ }^{54}$ G. Kossinna, Die Deutsche Vorgeschichte: eine Hervorragend Nationale Wissenschaft, "Mannus-Bibliothek", 9, 1921 [1914]. 


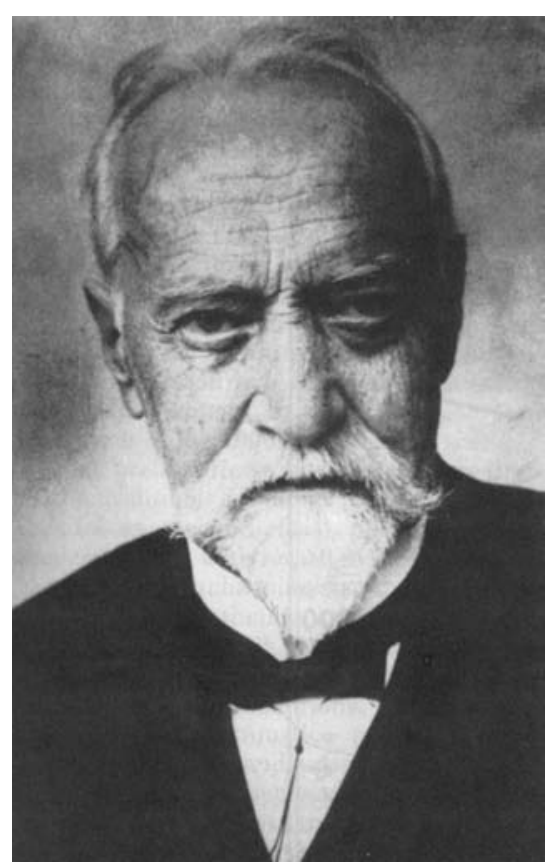

Fig. 6 - O arqueólogo Gustav Kossinna em 1931.

obtivesse qualquer resposta, como era de esperar, defendendo o direito alemão às regiões cedidas então à Polónia, recorrendo a testemunhos arqueológicos comprovativos de uma antiquíssima presença germânica ${ }^{55}$. Este episódio ilustra quer a combatividade de Kossinna, quer as ilusões a que frequentemente os intelectuais se permitem, nomeadamente os arqueólogos, acerca do poder ilusório das suas disciplinas junto dos políticos ${ }^{56}$.

Gustav Kossinna sucedeu, em 1902, a Rudolf Virchow como figura principal da ciência pré-histórica alemã, embora a sua formação original se situasse na área da Linguística. Muito activo, ficou a dever-se-lhe a criação, em 1909, da Geselschaft für Deutsche Vorgeschichte, em Berlim. Kossinna apoiava as suas teorias no conceito de que os artefactos (fósseis directores) permitiam identificar áreas culturais específicas (Kulturprovinzen), representativas de grupos étnicos precisos. Este conceito arqueológico de Cultura, entendido como

${ }^{55}$ G. Kossinna, Die deutsche Ostmark: ein Heimatboden der Germanen, Berlim, 1919.

${ }^{56}$ H. Eggers, Einfuhrung in die Vorgeschichte, Munique, 1986, p. 236. O Poder da Arqueologia não passa, como é evidente, de uma perigosa ilusão dos especialistas, limitando-se, quase sempre, a um simples reflexo de interesses políticos, mais ou menos evidentes. 
um conjunto de testemunhos materiais produzidos por um grupo considerado homogéneo, foi, e é ainda, largamente utilizado pelos arqueólogos ${ }^{57}$. O problema de Kossinna, cujo contributo para o progresso da Arqueologia não é desprezível, foi o de ter situado a origem dos povos indoeuropeus no Norte da Alemanha e na Escandinávia, defendo vigorosamente um fenómeno de difusão que teria levado à germanização de vastíssimas regiões, bem como ter advogado a superior condição dos que considerava, sem hesitações, ascendentes dos alemães históricos. Na defesa das suas teorias associadas à ideia de Kulturkreis, Kossinna envolveu-se em polémica, a propósito do texto que enviou a Versalhes, com um dos seus mais destacados discípulos, o polaco J. Kostrezewski, que se opunha à ideia da colonização germânica das áreas cedidas à Polónia, usando exactamente os mesmos argumentos arqueológicos para provar a anterioridade da presença eslava ${ }^{58}$.

Difusionismo e migracionismo constituiram conceitos operacionais muito úteis aos ideólogos alemães, o que, só por si, não pode ser desculpa para a sua quase exclusão do discurso arqueológico. A ideia de um centro a partir do qual a civilização se espraiou em várias direcções, se interpretada de forma restrita e racional, permanece válida e foi utilizada por numerosos arqueólogos, entre os quais muitos que, como Gordon Childe, não podem ser considerados entusiastas das teses desenvolvidas a partir das teorias de Kossinna ${ }^{59}$. Não era o método que estava errado, mas sim muitas das conclusões que dele se extraíam. Os escritos de Kossinna, de qualquer forma, permitiram desviar para solo europeu as atenções dos arqueólogos, obrigando a reconsiderar as hipóteses que situavam o princípio de determinados fenómenos culturais noutras regiões, levando a admitir a possibilidade de desenvolvimentos paralelos e independentes.

Que nos seja perdoada esta longa referência à acção de Gustav Kossinna, necessária numa época em que figuras como Vickie, o Viking ou Astérix, o Gaulês, continuam a popularizar as velhas imagens do Germanismo e do Celtismo, com o estrondoso êxito que se lhes conhece, para mais fácil compreensão do que se passou na Alemanha a partir de 1933. O processo de integração da Arqueologia na política de subordinação total das actividades culturais e científicas às directrizes do partido nacional-socialista (NSDAP) foi muito rápido, tal como sucedeu em muitas outras áreas de actividade na Alemanha. Esta rapidez não deixa de impressionar, sobretudo pelos resultados materiais visíveis e largamente

${ }^{57}$ V. G. Childe, Introdução à Arqueologia, Lisboa, 1961, p. 13-20; J. Malina / Z. Vašíček, p. 61-66.

${ }_{58}$ Arnold, Past, p. 467.

59 Jones, p. 15-26. 
difundidos pelos múltiplos meios de propaganda disponíveis, eficientes e de boa qualidade, mas não deixou de ser prejudicada por uma evidente carência de amadurecimento, inclusive no campo dos equipamentos militares, como o decorrer da guerra revelaria dramaticamente.

Uma das consequências, a nível das actividades arqueológicas, foi a de se estabelecer uma certa dualidade, não isenta de conflitos, sobretudo em relação à Pré-História, entre as duas entidades que vão estruturar a arqueologia alemã até 1945, a Amt Rosenberg e a Studiengeselschaft für Deutsches Ahnenerbe, a primeira dirigida por Alfred Rosenberg, a segunda pelo Reichsführer SS, Heinrich Himmler. A luta pelo controlo absoluto da arqueologia pré-histórica desenvolvida entre as duas organizações impediu a concretização de um plano de Rosenberg para impôr um organismo que tutelasse toda a actividade arqueológica alemã, a Reichsbund für Deutsche Vorgeschichte. Alguns arqueólogos, sem questionarem os princípios fundamentais defensores da superioridade germânica, aproveitaram a situação, escavando com a melhor metodologia da época, caso de F. Langsdorff e de H. Schleif, cuja atitude equilibrada na Ahnenerbe contribuíu para limitar parte dos excessos característicos da forma como funcionava esta organização, criada em 1933 por H. Wirth, um pré-historiador holandês, W. Darré e W. Sievers, organização que Himmler associou às SS em $1935^{60}$.

Rosenberg, de formação filosófica, redigiu um volumoso livro, publicado em 1930, de enorme popularidade, no qual, entre as esperadas banalidades ${ }^{61}$, se encontram fantásticas afirmações, entre as quais referências à Atlântida como uma realidade comprovada e à origem ariana de Jesus Cristo. A figura principal na Amt Rosenberg foi, até 1945, Hans Reinerth, um arqueólogo muito experiente, que escavou largamente na Alemanha e no estrangeiro e que publicou, nos últimos meses da guerra, uma importante obra de síntese, fundamental para compreensão dos objectivos e dos métodos da organização, na qual era o segundo na hierarquia, intitulada Vorgeschichte der Deutschen Stämme:

${ }^{60}$ Sobre estas duas organizações e seu protagonismo: R. Bollmus, Das Amt Rosenberg und seine Gegner: zum Machtkampf im Nationalsozialistichen Herrschaftssystem, Estugarda, 1970; M. Kater, Das Ahnenerbe der SS 1935-1945. Ein Beitrag zur Kulturpolitik des Dritten Reiches, Munique, 1997. É provável que os excessos visionários de Wirth tenham conduzido à sua substituição na Ahnenerbe, em 1937, por Walter Wüst. Seria muito interessante desenvolver uma análise distinguindo o trabalho meramente arqueológico, ainda que condicionado ideologicamente, das fantásticas elucubrações dos mitómanos como Wirth ou Wiligut.

${ }^{61}$ A. Rosenberg, Der Mythus des 20 Jahrhunderts, Munique, 1930. 
Germanische Tat und Kultur auf deutschen Boden ${ }^{62}$. A Ahnenerbe contava com um grupo de ultras muito activo, embora francamente minoritário, parte integrante dos apropriadamente chamados Germanomen (Germanomaníacos), criticados com frequência pelos seus excessos na criação de um pretenso passado germânico, nocivo à ideia de actividade científica que a organização pretendia transmitir, inclusive nas universidades. Uma das publicações mais populares da Ahnenerbe, o mensário Germanenerbe (Fig. 7), fez-se por vezes porta-voz dessas críticas, compartilhadas por altos responsáveis do partido, incluindo o próprio Hitler ${ }^{63}$.

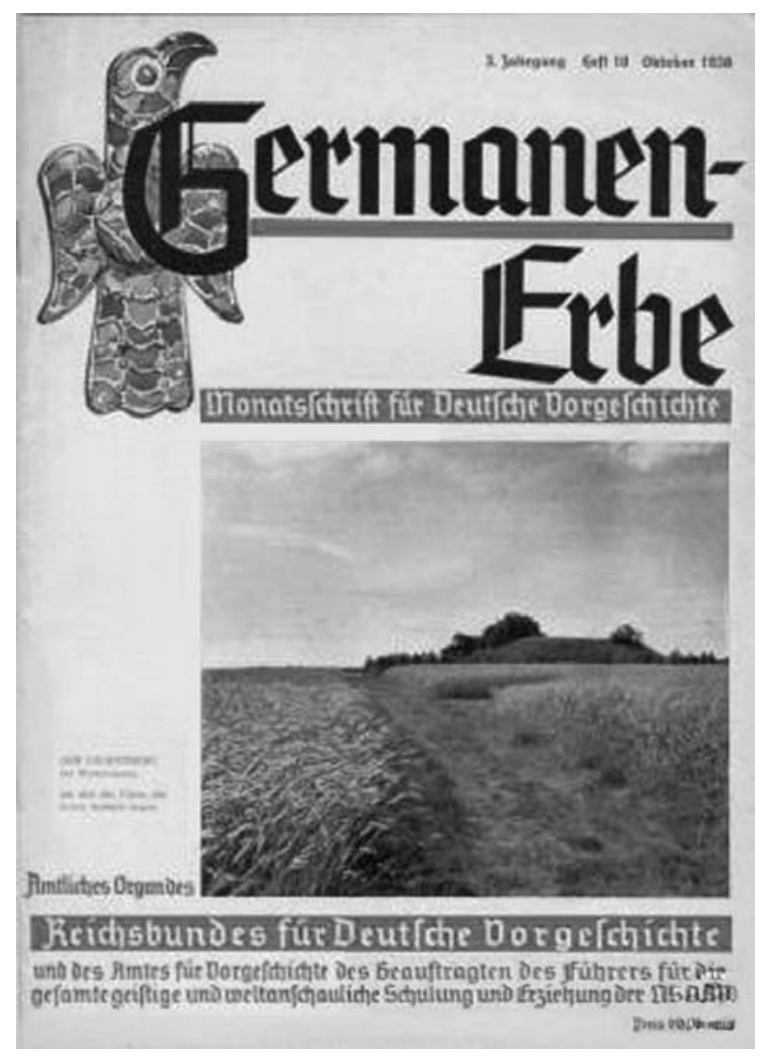

Fig. 7 - Capa da revista Germanenerbe (Outubro de 1938).

${ }^{62}$ H. Reinerth, Vorgeschichte der deutschen Stämme: Germanische Tat und Kultur auf deutschem Boden, I-III, Berlim, 1945.

${ }_{63}$ Arnold, Past, p. 469-471. 
Entre os extremistas destacaram-se, na organização das SS, os nomes de Hermann Wirth e de Wilhelm Teudt. O primeiro pretendia situar, a partir de um documento apócrifo, a Crónica de Ura-Linda, no Norte da Europa a origem da Civilização Ocidental, enquanto que o segundo difundiu uma série de insustentáveis teorias sobre templos germânicos e observatórios solares, em consequência das conclusões que desenvolveu sobre a formação natural de Extersteine, perto de Detmold, onde monges medievais abriram uma série de galerias ${ }^{64}$. Embora Ernst Jünger identifique Braquemart com outras figuras, a verdade é que a descrição das descobertas arqueológicas atribuídas à sua personagem literária sugere de perto o tipo de coisas que ocorrem nos escritos de Wirth e de Rosenberg, combinando ideias expostas por ambos e reflectindo uma certa influência da Atlântida de Pierre Benoit ${ }^{65}$. Na realidade, muitos dos trabalhos que aqui consideramos estão mais perto da literatura de ficção do que da investigação científica. Esta circunstância obriga a recordar que os objectivos de muita desta produção eram totalmente políticos, mas mesmo que só parte dos seus autores acreditasse no que escrevia, tiveram enorme aceitação pública. Numa época em que se multiplicam livros e filmes inspirados em pretensos mistérios, segredos e descobertas, quase sempre roçando ou cultivando descaradamente a charlatanice pura e simples, com enorme receptividade de um público acrítico e não menores lucros para quem os produz, é admissível que nos admiremos com o que se passou num regime totalitário? O imaginário fantástico é sempre bem recebido por sociedades em crise e os mitos ajudam a suportar o insuportável, projectando o homem para um plano intemporal, onde os sonhos talvez se concretizem, libertando-o assim da condição de ser para $a$ morte que Heidegger lhe atribuíu.

A Ahnenerbe ganhou gradualmente importância, face às inconsequências da Amt Rosenberg e à maior operacionalidade e disciplina organizativa da entidade dependente de Himmler. Uma das ideias de Rosenberg que não agradou aos arqueólogos foi a da tutela repartida das escavações de sítios com diversos períodos representados, dificuldade bem conhecida e nem sempre convenientemente resolvida, que Rosenberg pretendia dividir entre a sua organização, para os níveis considerados germânicos, medievais ou pré-históricos, e os níveis romanos, reservados à Römisch Germanische

${ }^{64}$ K. Jacob-Friesen, Herman Wirth's Ura-Linda-Chronik und die deutschen Vorgeschichtsforscher, "Nachrichtenblatt für Deutsche Vorzeit", 10, 6, 1934,p. 130-135; W. Teudt, Germanische Heiligtümer: Beiträge zur Aufdeckung der Vorgeschichte, ausgehend von den Extersteinen, den Lippequellen und der Teutoburg, 1934, Lippe.

${ }^{65}$ J. Hervier, Entretiens avec Ernst Jünger, Paris, 1986, p. 48; P. Benoit, A Atlântida, Lisboa, 1974, p. 88-97. 
Komission $^{66}$. Para além destas questões e dos atritos entre as duas organizações que dirigiram a arqueologia pré-histórica germânica, não há duvida quanto ao sucesso que ambas alcançaram na sensibilização da população alemã para o valor do património arqueológico, quer através de acções de divulgação muito diversificadas, quer através da criação de novos museus ou da exposição de materiais até então relegados nos depósitos dos já existentes como coisas sem interesse. As SS tiveram um papel muito importante neste processo, obedecendo ao pensamento de Himmler, que pretendia criar um centro de estudos do passado germânico em todos os locais onde existisse uma unidade da organização ${ }^{67}$. A enfâse posta na observação atenta e no respeito pelo mais pequeno fragmento de cerâmica, como documentos dos nossos antepassados, é permanente e entusiástica. Nenhum arqueólogo contemporâneo teria relutância em subscrever este tipo de apelos, onde ainda hoje se confundem, quando destinados a um meio não especializado, ancestralidade e cultura ${ }^{68}$, deixando pairar a dúvida sobre quem são esses antepassados, o que, naturalmente, não acontecia na Alemanha nacional- socialista.

A divulgação da mensagem política e do gosto pelo passado que comportava, como um motivo de orgulho nacional, foi perfeitamente adaptada aos diferentes públicos potenciais, englobando, na prática, toda a população alemã (Fig. 8), no que foi apoiada por publicações muito populares, como Die Kunde(AMensagem) e Germanenerbe (A Herança Germânica), assim como por um caudal permanente de artigos em jornais e revistas de grande circulação e, com frequência, de notável qualidade $^{69}$. O modernismo, naturalmente germanizado, que caracterizou muitas iniciativas culturais do III Reich revelou-se também através de reconstituições pioneiras de sítios arqueológicos, como no caso do estabelecimento Neolítico e da Idade do Bronze de Unteruhldingen, no Lago Constança, que contribuíram eficazmente para uma imagem muito apelativa do passado germânico, de grande impacte na imaginação popular, estimulada ainda pela projecção dada a outros sítios, como Alt-Christburg, na Prússia Oriental, à guarda dos $\mathrm{SS}^{70}$.

${ }^{66}$ Arnold, Past, p. 473-474.

${ }^{67}$ Landemer, p. 53.

${ }^{68}$ Arnold, Past, p. 468; Jones, p. 141.

${ }^{69}$ Recordamos, a propósito da qualidade das publicações, a favorável opinião de Günter Grass acerca da excelente revista Signal, também disponível em edição portuguesa durante grande parte da II Guerra Mundial: G. Grass, O Meu Século, Lisboa, 2001, p. 112.

${ }^{70}$ Arnold, Past, p. 468; F. Langsdorff / H. Schleif, Ausgrabungen auf dem Schlossberg von Alt-Christburg, Kr. Mohrungen, "Nachrichtenblatt für Deutsche Vorgeschichte", 13, 4, 1937 , p. $80-82$. 


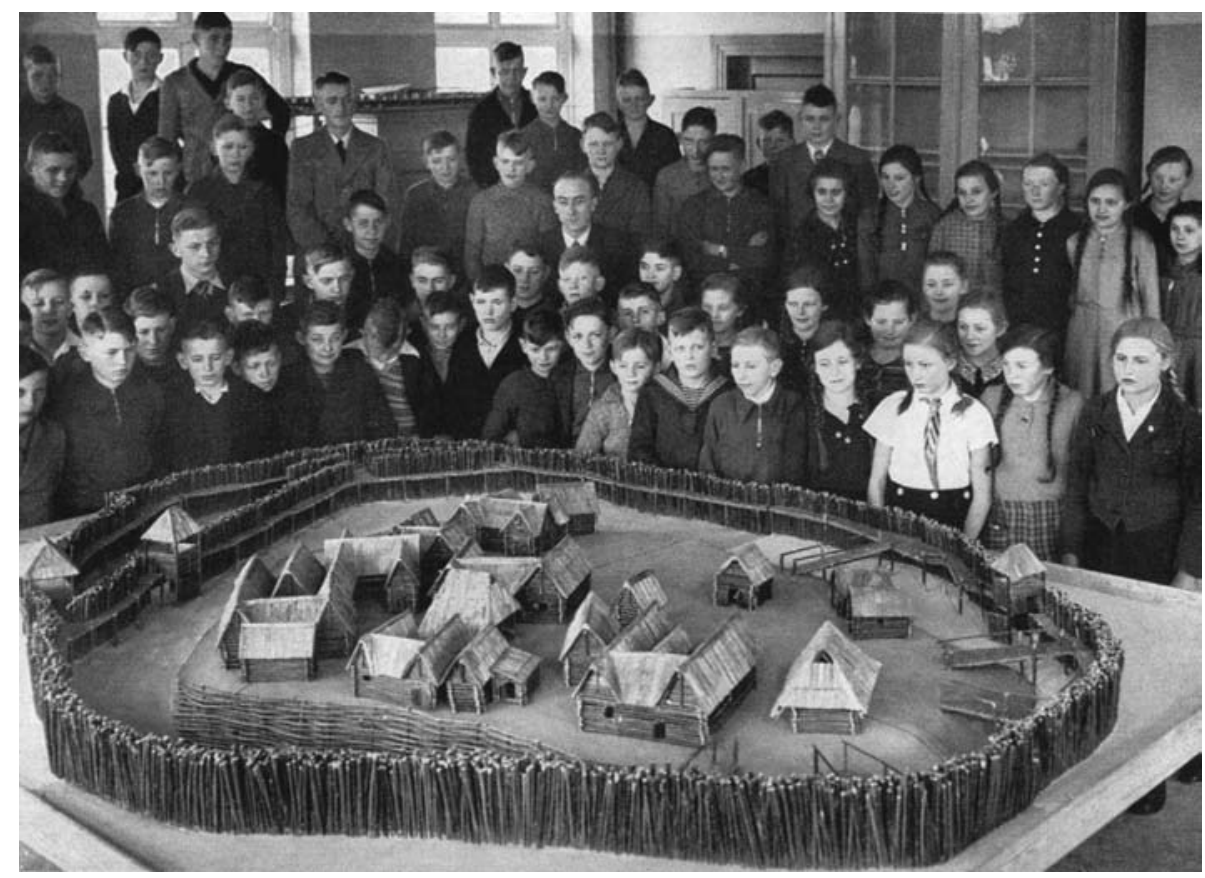

Fig. 8 - Um grupo de jovens estudantes observa a maqueta de um povoado da Idade do Bronze (Wasserburg, Buchau).

A propaganda constante em torno das pesquisas pré-históricas como um projecto nacional canalizou inúmeros amadores entusiastas e organizações locais para trabalho voluntário no âmbito dos programas da Amt Rosenberg e da Ahnenerbe. Todo este processo, invulgar para a época na maior parte dos países, pela envergadura das acções, meios e técnicas utilizadas, contava, naturalmente, com visitas de grupo a sítios e a museus, ciclos de palestras e campos de trabalho mistos, com significativa presença de elementos femininos, onde a componente de formação ideológica era muito importante. Podemos ainda relacionar com a difusão de um heróico imaginário germânico, na linha das teses de Kossinna, algumas das pequenas viagens efectuadas por navios da Kraft durch Freude, nomeadamente à ilha dinamarquesa de Bornholm e aos fiordes da Noruega. Durante as viagens, parte do tempo era ocupado, como seria de esperar, com acções de formação política, onde não faltavam as referências à grandeza do passado germânico.

A Ahnenerbe, utilizando os vastos recursos das SS, escavou muito na Alemanha e nos países ocupados, com especial destaque para sítios localizados no Leste europeu, para além de ter subsidiado viagens de exploração no estrangeiro, 
algumas das quais serviram de inspiração para os filmes de Steven Spielberg da série Indiana Jones. Estas escavações, maioritariamente realizadas em sítios pré-históricos ou do período que oficialmente se passou a designar como Germânico Tardio, equivalente grosso modo à fase entre os séculos IV e VIII, obedeciam a objectivos prioritariamente políticos, sobretudo preocupados em comprovar a presença de populações germânicas em áreas reinvindicadas pelo Reich, justificadas ou não, a partir dos testemunhos arqueológicos de uma cultura material que lhes era atribuída. Algumas destas escavações tiveram como cenário sítios de primeira importância, como a grande feitoria comercial viking de Haithabu (Hedeby), no litoral báltico de Scheslwig-Holstein (Fig. 9), escavada sistematicamente, por Herbert Jankuhn, a partir de 1938 com supervisão das $\mathrm{SS}^{71}$, ou ainda o conhecido sítio pré-históricos de Köln-Lindenthal, escavado por W. Buttler ${ }^{72}$. As escavações de Haithabu e as de Köln-Lindenthal

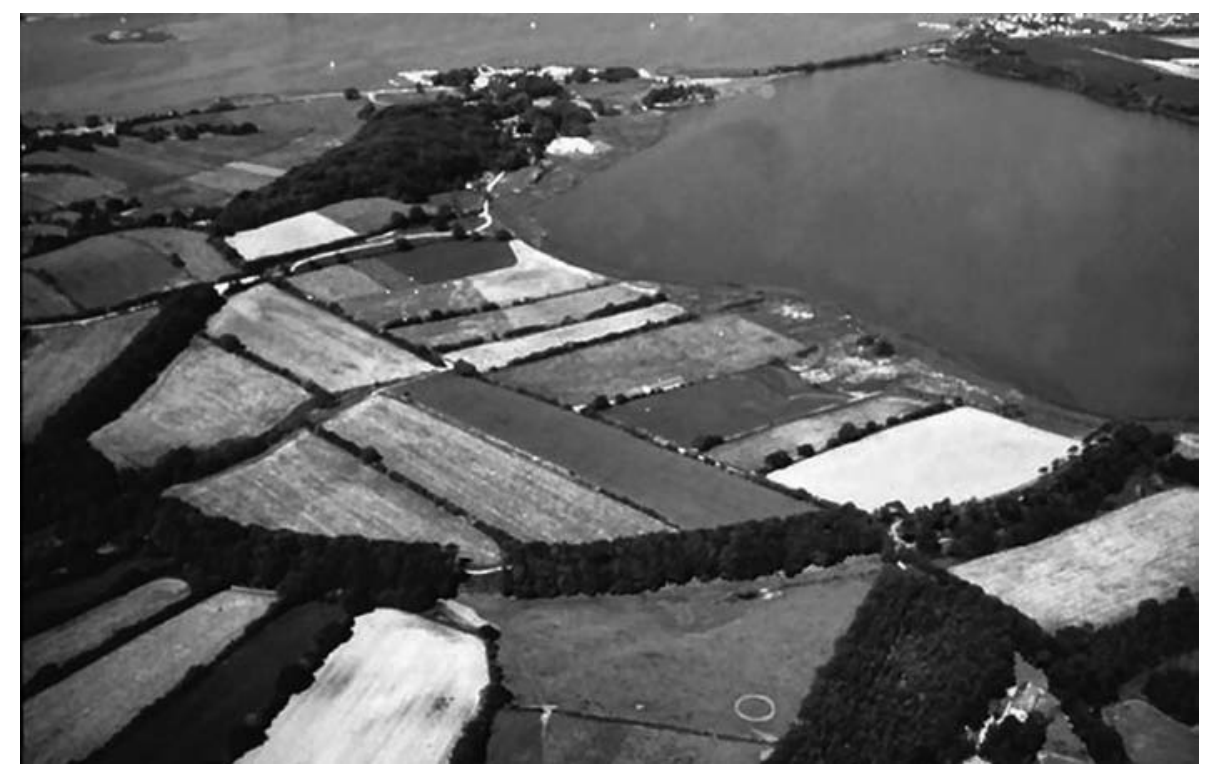

Fig. 9 - O sítio viking de Haithabu, der erste Ostseehafen des Deutschen Reiches.

O percurso da muralha de terra é particularmente visível na fotografia.

${ }^{71}$ H. Jankuhn, Die Wehranlagen des Wikingerzeit swischen Sclei und Treene, Neumünster, 1937; Die SS-Grabung von Haithabu 1939, "Nachrichtenblatt für Deutsche Vorzeit", 16, 4-5, 1940, p. 103-104.

${ }^{72}$ W. Buttler / W. Haberey, Die bandkeramische Ansiedlung bei Köln-Lindenthal, Berlim, 1934. 
podem considerar-se modelos da metodologia a observar na escavação de estabelecimentos neolíticos e alto-medievais, cujas dificuldades todos os arqueólogos reconhecem.

Muitas escavações menores deixaram pouca informação, por falta de publicação ou porque se perderam os seus relatórios nos bombardeamentos aéreos e no turbilhão do final da guerra. Essas escavações, inseridas com frequência nos programas de doutrinação ideológica da juventude e falhas de qualidade científica, uniram amadores de arqueologia, soldados, sobretudo das SS, membros do Serviço de Trabalho (Arbeitsdienst), alunos das Ordensburgen ${ }^{73}$, assim como habitantes das zonas onde se desenvolviam os trabalhos. As escavações efectuadas na Westmark (Alsácia-Lorena), em busca de testemunhos do período franco e carolíngio, com a participação de militares e conduzidas por arqueólogos do Museu de Mainz, são um bom exemplo deste tipo de trabalhos arqueológicos ${ }^{74}$. Nas regiões ocupadas, os monumentos de origem germânica foram correntemente utilizados como fortes elementos simbólicos na propaganda alemã, sobretudo em regiões tradicionalmente disputadas desde a Idade Média e consideradas como territórios integrantes do Reich (Fig. 10).

Os aspectos políticos do envolvimento das SS na Arqueologia levam-nos à pertinente e actualíssima questão da destruição de património arqueológico como represália ou como objectivo seleccionado, no intuito de apagar os testemunhos visíveis de um determinado passado. Daremos apenas como exemplo destas situações as destruições executadas no importante sítio da Idade do Ferro de Biskupin, na Pomerânia polaca, quando as tropas alemãs começaram a recuar na Frente Leste, em 1944, sítio onde a Ahnenerbe conduzira escavações até essa altura. Já o incêndio que destruíu os navios romanos no Museu de Nemi, em Itália, por muitos atribuído a soldados alemães em retirada, em 1944, continua sem explicação consensual ${ }^{75}$. Falamos, como é evidente, de situações de destruição à margem de operações militares, causadoras dos agora tão falados danos colaterais. A destruição do Castelo de Könisgsberg pelos soviéticos,

${ }^{73}$ Langsdorff / Schleif, p. 82; Arnold, Past, p. 474. As Ordensburgen eram escolas de formação de quadros do NSDAP, aliando a educação normal da juventude a uma enérgica formação física e ideológica.

${ }^{74}$ I. Bardiès / J.-P. Legendre, Alsace et Moselle au temps de l'annexion (1940-1944), "Archéologia", 380, 2001, p. 12-18.

${ }^{75}$ Sklenar, p. 83. Em relação à destruição dos navios romanos recuperados por iniciativa de Mussolini no Lago Nemi, as opiniões divergem: acto de represália alemão, incêndio para encobrir o roubo do metal das chapas de revestimento do casco dos navios ou vingança política contra um dos símbolos mais conhecidos da actividade arqueológica do regime fascista. As dúvidas persistem: J. Meirat, Marines antiques de la Mediterranée, Paris, 1964, p. 154-159. 


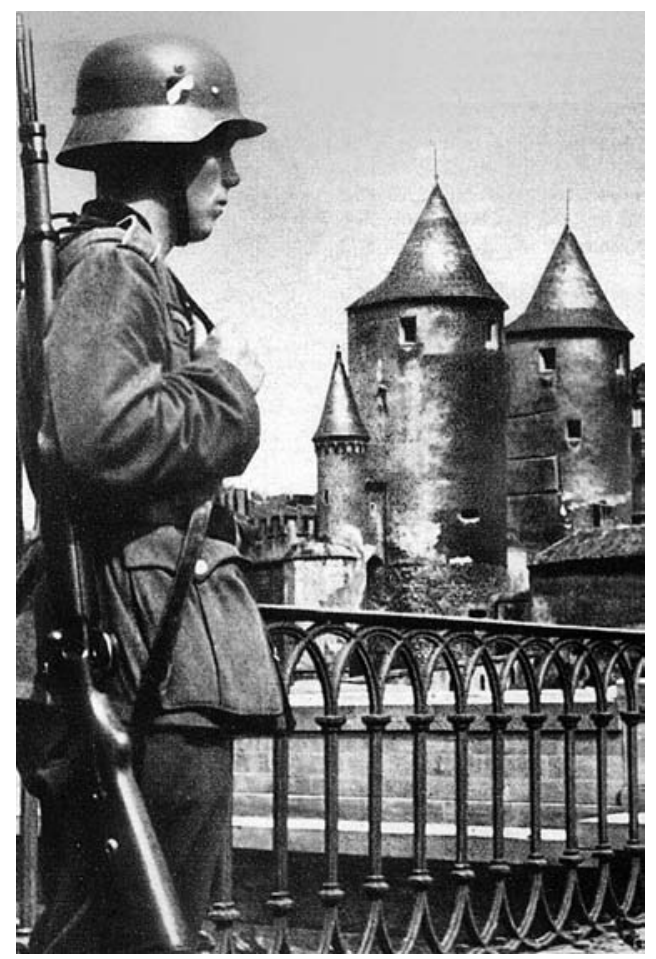

Fig. 10 - A Porta dos Alemães, em Metz (França), num folheto de propaganda alemã sobre a Alsácia-Lorena.

após o final da guerra, por ser considerado um símbolo do militarismo prussiano, ilustra bem o que dizemos e prova, se fosse necessário fazê-lo, que este tipo de destruições não foi exclusivo de uma das partes envolvidas no conflito ${ }^{76}$.

A orientação nacional-socialista da arqueologia teve também influência na tentativa de recriar mitos e festividades consideradas germânicas, pré-cristãs, recorrendo a um misto ambíguo de conhecimentos e suposições. A festa do Natal foi relacionada com a celebração pagã do regresso da luz, ganhando especial

${ }^{76} \mathrm{O}$ Castelo de Königsberg, imponente construção medieval e renascentista, foi muito atingido pelos bombardeamentos aéreos ingleses, em Agosto de 1944, e depois pelos combates pela posse da cidade. Em 1950, concluída a russificação da antiga capital prussiana, foi demolida a imponente Torre do Relógio e em 1968 os restos do monumento foram completamente arrasados. No seu lugar foi construído o Palácio dos Sovietes, abandonado desde 1991 e só recentemente terminado e recuperado para fins administrativos e empresariais. Na verdade, da cidade de Kant pouco sobreviveu à guerra e às destruições que se lhe seguiram. 
evidência a comemoração do solstício de Verão e a Festa das Colheitas, no primeiro Domingo de Outubro. O solstício de Verão foi celebrado num vigoroso poema de Hans Leifhelm intitulado Bauernspruch zur Sommersonnwend, o qual permite recuperar o ambiente próprio destas festividades fortemente enraízadas na tradição nórdica ${ }^{77}$. Isto não era suficiente para a visão dos grandes antepassados acalentada por Himmler, que fazia os SS participarem nessas festividades, de cunho marcadamente neo-pagão ${ }^{78}$. Fizemos já referência ao caso muito conhecido de Extersteine, nesta busca de lugares de culto germânicos, o qual não é o único. O desenvolvimento de uma nova religião, inspirada na mitologia nórdica, no culto solar e na fidelidade ao sangue, teve considerável impulso, logo a partir de 1933. Em 1935 havia uma dúzia de locais classificados como Thingstätte, sobre testemunhos reais ou imaginados da presença cultual germânica, como aconteceu nos arredores da académica Heidelberga, no cume do Heiligenberg ${ }^{79}$. Estes locais eram equipados com teatros ao ar livre, destinados a festividades, comemorações e representações reflectindo a nova ordem religiosa. A resistência pressentida dos cristãos alemães levou o ministro da propaganda, Joseph Goebbels, a suspender o programa em 1935, o mesmo ano em que a Ahnenerbe passou para o controlo de Himmler. Muito ilustrativo desta orientação cultural é o episódio de Sachsenhain, na região de Werden, onde foram massacrados pelas tropas de Carlos Magno quatro mil e quinhentos Saxões que recusaram converter-se ao Cristianismo. Aqui, os SS utilizaram igual número de blocos de pedra para reconstituir casas do tipo que se presumia corresponder à Alta Idade Média na região, honrando simbolicamente a fidelidade à tradição ${ }^{80}$.

A enorme valorização que as obras de Richard Wagner conheceram sob o regime nacional-socialista, com especial relevo para a Tetralogia, insere-se, naturalmente, na concepção do passado que interessava divulgar, quer do passado mítico germânico, quer de um imaginário medieval alemão repleto de misticismo, que os SS tentarão recriar no Castelo de Wewelsburg, na Vestefália. Poderíamos ainda considerar a possibilidade das obras wagnerianas serem

${ }^{77}$ H. Leifhelm, Bauernspruch zur Sommersonnwend, "Anthologie Bilingue de la Poésie Allemande”, (Coord. R. Lasne), 2, Verviers, 1967, p. 284-286. Eis o início do poema: Wir treten zusammen in einen Kreis / Und brennen das Feuer nach Alter weis'/ Wir brennen das Feuer, so wie es getan / Zu ihren Zeiten der Vater und Ahn.

${ }^{78}$ Landemer, p. 53. Um dos mais exacerbados criadores deste pretenso passado germânico, no qual se incluía uma religião centrada num deus que se teria chamado Krist, foi o austríaco K. M. Wiligut, membro destacado da Ahnenerbe até 1938.

${ }^{79}$ Arnold, Propaganda, p. 34-36.

${ }^{80}$ Landemer, p. 53-54. 
interpretadas como um ataque à burguesia, tal como já foi proposto no século XIX, muito antes da justamente polémica encenação da Tetralogia dirigida por Pierre Boulez em Bayreuth, nos anos 70 do século passado ${ }^{81}$. Cremos, todavia, que o reforço da imagem germânica através da arte de Wagner terá constituído o objectivo principal. Tudo o que dissemos, embora não directamente relacionado com a Arqueologia, pertence ao mesmo contexto político-cultural, característico da orientação estatal e da utilização cruzada de todos os elementos que contribuissem para a desejada imagem do passado alemão.

Os exageros que se verificaram na utilização da Arqueologia e, de uma maneira geral, de tudo o que servisse o ideal germânico, não deixou de criar algumas reticências entre as figuras mais realistas pertencentes à chefia do Estado. Goebbels apercebeu-se rapidamente da necessidade de controlar tais exageros e o próprio Hitler criticou, segundo testemunho de Albert Speer, os efeitos perversos da política de promoção de um passado germânico incapaz de sustentar qualquer comparação vantajosa com outros contemporâneos: Porque havemos de chamar a atenção de todo o mundo para o facto de que não temos passado? É já suficientemente mau que os Romanos erigissem grandes edifícios enquanto os nossos antepassados ainda viviam em cabanas de lama; agora Himmler começa a escavar essas aldeias de cabanas de lama e entusiasma-se com cada caco de cerâmica ou machado de pedra que encontra. Tudo o que provamos assim é que ainda lançávamos machados de pedra e nos acocorávamos à volta de fogueiras quando a Grécia e Roma já tinham atingido o mais elevado grau de cultura. Deveríamos fazer o nosso melhor para manter sossegado este passado. Ao contrário, Himmler faz um grande espalhafato à volta de tudo isto. Os Romanos de hoje devem rir-se destas revelações ${ }^{82}$.

Esta crítica, perfeitamente de acordo com a admiração de Hitler pela civilização greco-romana, permite compreender o problema que se levantou aos responsáveis políticos alemães quando era necessário escolher alguma coisa que exprimisse a grandeza do Estado, em particular na arquitectura. A resposta teve em conta, inevitavelmente, na ausência de modelos disponíveis que pudessem aludir directamente à antiguidade germânica, inexistentes, a herança do classicismo e a inspiração da arquitectura profana medieval alemã. A linha clássica, presente nas propostas de Albert Speer para a remodelação de Berlim (Fig. 11), ou, por exemplo, na evocadora tribuna do Zeppelinfeld, em Nuremberga, directamente inspirada no Altar de Zeus, em Pérgamo, foi a que mais marcou a arquitectura do Reich hitleriano, com larga inspiração nos grandes monumentos

${ }^{81}$ Dahn, p. 117 (nota do tradutor); Stürmer, p. 61-62.

${ }^{82}$ A. Speer, Inside the Third Reich, Nova Iorque, 1970, p. 94-95. 


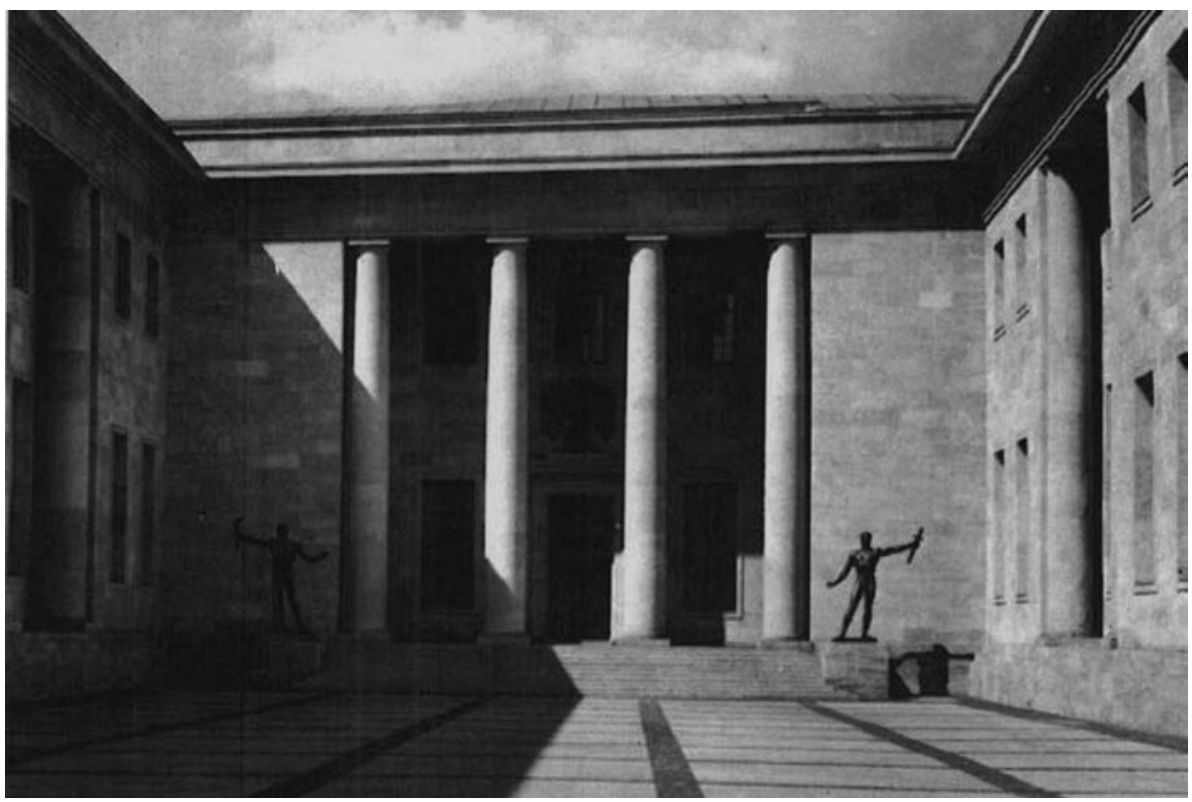

Fig. 11 - Pátio de honra da Nova Chancelaria, em Berlim, delineado por Albert Speer e decorado com esculturas de Arno Brecker.

imperiais romanos, motivadora da teoria do Valor da Ruína, desenvolvida por Speer, a qual pretendia que os grandes monumentos do Reich, quando se transformassem em ruínas, deveriam ter o mesmo aspecto imponente das construções romanas. O início da guerra impediu que a maior parte destes ambiciosos projectos, nos quais colaboraram muitos e distintos arquitectos, como o ostracizado e depois recuperado Wilhelm Kreis, se concretizasse ${ }^{83}$. A linha propriamente alemã, combinando o modernismo nórdico com elementos medievais estilizados produziu obras interessantes, incluindo algumas das grandes Ordensburgen, como a de Vogelsang (Fig. 12), incluindo por vezes também soluções que se podem aparentar com a estrutura das grandes casas comunitárias pré-históricas, como as que foram escavadas em Köln-Lindenthal.

O gosto pessoal de Hitler e de Speer pesaram de forma decisiva no que foi a arquitectura monumental alemã da época, tanto mais que a Alemanha conhecera anteriormente uma fortíssima corrente neoclássica, de que a Porta de Brandenburgo, em Berlim, representa o exemplo mais conhecido e de

${ }^{83}$ L. Krier, Albert Speer Architecture, Nova Iorque, 1989; W. Nerdinger / E. Mai (Coord.), Wilhelm Kreis - Architekt Zwischen Kaiserreich und Demokratie 1873-1955, Munique, 1994. 


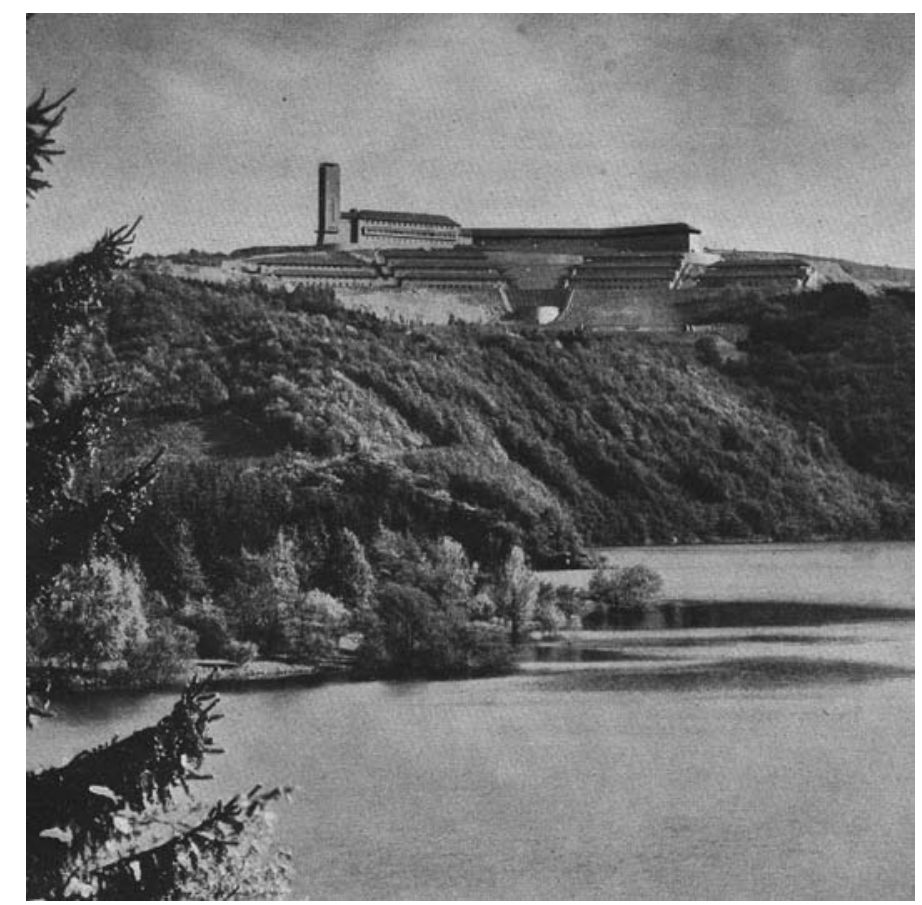

Fig. 12 - A Ordensburg de Vogelsang, projecto de Clemens Klotz invocando a estrutura de uma grande fortaleza medieval.

maior valor simbólico. A opção pela estética clássica como forma de projectar a ideia da superioridade do Estado resultou de forma quase natural, mas não deixa de invocar o dualismo Germanismo-Classicismo, patente na orientação da arqueologia alemã, e que, a nível da arquitectura oficial permite vislumbrar uma tendência mais francamente germanizante por parte de certas forças no interior do Estado, caso das SS. A valorização da Antiguidade Clássica esteve presente noutras formas de expressão artística, como a escultura monumental, caso, por exemplo, das obras de Arno Brecker ou, não o esqueçamos, no cinema, também utilizado para divulgar o passado germânico, mas onde os dois filmes de Leni Riefenstahl sobre os Jogos Olímpicos de Verão de 1936 constituem um vigoroso hino ao legado clássico e aos seus novos detentores nórdicos ${ }^{84}$.

${ }^{84} \mathrm{O}$ filme sobre as Olimpíadas, genericamente denominado Olympia teve a primeira exibição em 1938, contando com duas partes: Fest der Völker e Fest der Schöneit. A cineasta foi galardoada por esta produção, como já fora antes, pela produção do famigerado Triumph des Willens, ao qual foi atribuído o grande prémio e a medalha de ouro na Exposição Internacional de Paris de 1937. Sobre o filme olímpico: C. C. Graham, Leni Riefenstahl and Olympia, Lanham, 2001. Sobre Arno 
Uma análise profunda dos aspectos da política cultural do III Reich, directa ou indirectamente relacionados com o Germanismo e com a utilização de argumentos arqueológicos em suporte das teses oficiais, ultrapassa os limites e os objectivos deste artigo. De tudo o que dissemos parece possível confirmar a existência de tensões entre germanistas e classicistas, as quais ultrapassaram largamente os aspectos científicos, revelando contradições em termos políticos e históricos, resolvidas através da reinterpretação dos mitos. A curta duração do III Reich deixa-nos na dúvida quanto ao que poderia ter acontecido posteriormente.

Alguns arqueólogos foram, depois de 1945, particularmente duros na condenação da arqueologia alemã e da cooperação que muitos investigadores prestaram à propaganda nacional-socialista, em particular no tocante às questões raciais e territoriais ${ }^{85}$. A este propósito ocorre-nos dizer que estes dois aspectos eram essenciais na ideologia do regime e que tais condenações parecem esquecer as características do Estado totalitário e a importância fundamental da propaganda. Lembramos que a Ahnenerbe se orientava segundo três vectores determinantes: a herança nórdica (Erbe), o espaço territorial (Raum) e o espírito (Geist). Esta circunstância ilustra a total impossibilidade de se desenvolver investigação científica isenta, sobretudo na área da Pré-História, numa sociedade em que o Estado confiscara a liberdade individual em troca de um conceito de grandiosa comunidade nacional. Devemos, por isso, moderar críticas fundamentalistas, fáceis de formular por parte de quem não viveu directamente os acontecimentos e que recorrem, muitas vezes, a uma terminologia que gostaríamos não encontrar em círculos académicos.

As consequências do que se passou entre 1933 e 1945 e da catástrofe que assolou a Alemanha e dos seus efeitos nos anos que se seguiram, foram muitos graves para a arqueologia alemã e ainda persistem parcialmente. Não falamos apenas dos problemas metodológicos e de uma certa atitude de reserva, determinando um vazio silencioso em torno do passado, fenómeno que de forma alguma se limita a esta questão da vida alemã nos anos 30 e 40 do século passado. As enormes,

Brecker: J. Petropoulos, From seduction to denial: Arno Brecker's engagement with National Socialism, "Art, Culture, and Media under the Third Reich", Chicago, 2002, p. 212-223.

${ }^{85}$ São muitas as críticas ao episódio infeliz que constituíu a submissão da arqueologia alemã à orientação política nacional-socialista. Sem querer ignorar uma realidade histórica, incómoda para todos, entre outras coisas por demonstrar a evidente vulnerabilidade das Ciências Humanas, a ponto de permitir dúvidas quanto ao seu estatuto, julgamos que termos como prostituição ou perversão, ainda que compreensíveis, ignoram deliberadamente a realidade totalitária: $\mathrm{P}$. L. Kohl, Limits to a post-processual archaeology, "Archaeological Theory: who sets the agenda ?”, Cambridge, 1993, p. 15; Arnold, Past, p. 474-476. 
inimagináveis, perdas sofridas em instalações, bibliotecas e colecções arqueológicas desorganizaram profundamente a disciplina ${ }^{86}$, ao que devemos somar o aspecto ainda mais dramático da morte de um incontável número de arqueólogos e de estudantes universitários durante o conflito ou por razões directamente relacionadas com ele. A divisão da Alemanha, ou do que dela restou, também contribuiu para prolongar uma situação anormal, colocando os arqueólogos alemães em dois campos opostos, com todas as consequências conhecidas nestas situações.

Em resultado de tudo isto, a arqueologia alemã, sobretudo a arqueologia pré-histórica, remeteu-se a uma prática cautelosa, privilegiando o pragmatismo e os aspectos técnicos em detrimento das interpretações, em especial quando envolvam questões étnicas ${ }^{87}$. Recentemente, os arqueólogos alemães iniciaram um processo de análise da forma como funcionou a investigação arqueológica nos anos do Nacional-Socialismo, de que a exposição realizada em Trier é um excelente exemplo ${ }^{88}$. Que este processo de auto-análise (Historikerstreit) não é fácil demonstra-o a polémica que se desenvolveu no final dos anos 80 a propósito da criação do Museu Histórico Alemão, em Berlim, e do destino a dar a vestígios de instalações associadas à Nova Chancelaria hitleriana ${ }^{89}$. Uma polémica opondo este ano os governos alemão e polaco quanto à realização de uma exposição sobre as populações refugiadas e expulsas dos territórios perdidos pela Alemanha após a derrota ${ }^{90}$, conduz-nos aos problemas da actualidade, pois um dos temas mais debatidos na arqueologia alemã foi sempre o dos limites orientais da Germânia.

${ }^{86}$ É difícil calcular as perdas em vidas humanas e praticamente impossível contabilizar a imensa destruição que se abateu sobre Universidades, Museus e outras instituições ligadas à investigação arqueológica, a partir de 1943. Muitos materiais saqueados ou expropriados, aguardam ainda devolução, como sucede com numerosas peças de museus berlinenses, inclusive do Museu de Pérgamo. Para termos uma ideia aproximada do que foi o massacre das cidades alemãs, indescritível, nada melhor do que examinar as fotografias do final da guerra.

87 Jones, p. 3-5; Arnold, Past, p. 474-476.

${ }^{88}$ H.-P. Kuhnen (Coord.), Propaganda, Macht, Geschichte. Archäeologie an Rhein und Mosel im Dienst des Nationalsozialismus, Trier, 2002.

${ }^{89}$ K. Meyer, Digging Berlin's chamber of horrors, “Archaeology”, vol. 45, 4, 1992, p. 24-29.

${ }^{90} \mathrm{Em}$ Agosto de 2006 desenvolveu-se intensa polémica, envolvendo entidades governamentais alemãs e polacas, a propósito da oportunidade de uma exposição, apoiada pela Bund der Vertriebenen, na qual, entre outros episódios semelhantes, se historiava a expulsão de milhões de alemães dos diversos territórios ocupados pela União Soviética em 1945. Este brutal episódio tem sido muito raramente invocado, por razões evidentes. Sobre os acontecimentos no Leste alemão nos últimos meses da Segunda Guerra Mundial: A. Beevor, A Queda de Berlim. 1945, Lisboa, 2003. 
A este propósito parece-nos importante notar que a proposta de uma expansão eslava, desenvolvida pelo arqueólogo polaco K. Jazdzewski, seguindo o modelo de Kossinna, leva os limites eslavos a ocidente quase até ao Elba, coincidindo praticamente com a fronteira da zona de ocupação soviética, depois DDR, enquanto que parte do litoral da Prússia Oriental fica fora da referida zona de expansão, conformando-se com o actual território russo de Kalininegrad (Königsberg). Analisando o mapa em questão, pouco posterior ao final da II Guerra Mundial ${ }^{91}$, torna-se mais fácil compreender o pequeno texto, de exigente leitura, redigido no início dos anos 50 pelo historiador Franz Altheim, responsável em 1938 de uma grande viagem de estudo subsidiada pela Ahnenerbe ao Próximo Oriente, sobre a situação e missão do espírito germânico na fronteira da Europa ${ }^{92}$. O final da guerra foi marcado no Leste, com o beneplácito dos Aliados, por uma acção de limpeza étnica sem paralelo na história recente da Europa, remetendo as fronteiras alemãs para a célebre linha Óder-Neisse, aliás não totalmente respeitada, eliminando sem hesitações uma secular e autêntica presença alemã a oriente desse limite ${ }^{93}$. Este facto, numa Europa onde, apesar da Declaração de Helsínquia, as fronteiras continuam a mudar, obriga a reflexões incómodas sobre a fragilidade da Arqueologia enquanto subordinada a interesses não científicos e sobre a precaridade dos equílibrios conseguidos contra a corrente da História, levando-nos a recordar o que M. J. Rowlands escreveu há poucos anos: The expansion of archaeology's relation to nacionalism and ethnicity in the constrution of collective identity seems certain to continue. Partly the materiality of the archaeological record will assure this. Partly also the creation of alternative pasts is increasingly being used to legitimate land claims, ethnic territories and access to economic resources ${ }^{94}$.

${ }^{91}$ Jones, p. 6-7.

${ }^{92}$ F. Altheim, A Ásia a Caminho da Europa, Lisboa, s/d, p. 10-13.

${ }^{93} \mathrm{Na}$ Conferência de Potsdam, os Aliados cederam à União Soviética e à Polónia cerca de um quarto do território alemão, situando a fronteira na linha Óder-Neisse. Na verdade, este acordo, considerado provisório, não foi respeitado, uma vez que o Rio Óder foi ultrapassado em Stettin e que o Rio Neisse tomado como limite se situa a nordeste de outro com o mesmo nome. Esta fronteira, que implicou a destruição da Prússia, só foi reconhecida pelo governo da RFA em 1970, em condições muito discutíveis, nada tendo contribuído para a reunificação alemã, que acabou por resultar do processo de enfraquecimento e implosão da União Soviética. A fronteira actual da Alemanha corresponde, em parte, à do I Reich, por volta de 935: E. Bauer, História Polémica da Segunda Guerra Mundial, VII, Mem Martins, 1970, p. 174-175; Römer, p. 32-33, 44-56.

94 Rowlands, p. 141. 